\title{
Nociceptor Sensitization by Proinflammatory Cytokines And Chemokines
}

\author{
Michaela Kress*
}

Div. of Physiology, Department of Physiology, Medical Physics, Innsbruck Medical University, A-6020 Innsbruck, Austria

\begin{abstract}
Cytokines are small proteins with a molecular mass lower than $30 \mathrm{kDa}$. They are produced and secreted on demand, have a short life span and only travel over short distances if not released into the blood circulation. In addition to the classical interleukins and the chemotactic chemokines, growth factors like VEGF or FGF and the colony stimulating factors are also considered cytokines since they have pleiotropic actions and regulatory function in the immune system. Despite the redundancy and pleiotropy of the cytokine network, specific actions of individual cytokines and endogenous control mechanisms have been identified. Particular local profiles of the classical proinflammatory cytokines are associated with inflammatory hypersensitivity and suggest an early involvement of TNF $\alpha$, IL-1ß and IL-6. An increasing number of novel cytokines and the more recently discovered chemokines are being associated with pathological pain states. Besides acting as pro- or anti-inflammatory mediators increasing evidence indicates that cytokines act on nociceptors. Neurons within the nociceptive system express neuronal receptors and specifically bind cytokines or chemokines which regulate neuronal excitability, sensitivity to external stimuli and synaptic plasticity. A first step towards a more mechanistic and individual pain therapeutic strategy could be avoidance of hypersensitive pain processing by either neutralization strategies for the proalgesic cytokines or by shifting the balance in favour of antialgesic members of the cytokine-chemokine network.
\end{abstract}

Keywords: Hypersensitivity, inflammatory pain, unrepathic pain, neuroimmune interaction.

\section{HYPERSENSITIVITY AND NOCICEPTOR SENSITI- ZATION}

Tissue injury and inflammation commonly cause hypersensitivity of the affected body region, so that normally painful stimuli become more painful (hyperalgesia), and those usually associated with nonnoxious sensations evoke pain (allodynia). The neural bases for these sensory phenomena have been explored most extensively using heat injury and experimental arthritis as models. Heat and/or mechanical hypersensitivity is observed after burns, inflammation, nerve lesion and malignant tumour growth. In models of peripheral inflammation hypersensitivity has been attributed to sensitization of myelinated (Adelta) and unmyelinated (C) primary sensory neurons [1] that normally respond to potentially tissue damaging (noxious) stimuli. Since the first report on primary afferent fibres that responded only to damaging stimulation of the skin and therefore were termed nociceptors [2] our knowledge on the function of these fibres and their association with pain has increased substantially. Detailed analyses of nociceptor function have been performed and strict criteria are available for phenotyping distinct classes of nociceptors in mice, rats and men [1,3-6]. Nociceptors occupy a prominent functional position in fast information detection, transduction and transmission of potentially noxious stimuli. They can undergo plastic changes and nociceptor sensitivity is modulated by a plethora of

*Address correspondence to this author at the Div. Physiology, DPMP, Medical University of Innsbruck, Frit-Pregl-Str. 3, A-6020 Innsbruck, Austria; Tel: +43-512-9003-70801; E-mail: michaela.kress@i-med.ac.at mediators occurring in the extracellular space. These mediators activate ion channels or metabotropic receptors in the nociceptor membrane resulting in excitatory discharge or a drop of physical activation threshold frequently accompanied by an augmented response of single nociceptors to mechanical, heat or cold stimuli. These alterations result in hypersensitivity and/or ongoing pain $[7,8]$.

\section{ION CHANNELS FOR THERMAL AND MECHANI- CAL NOCICEPTIVE TRANSDUCTION}

In normal tissue, the sensation of heat pain occurs at a temperature of $\sim 44^{\circ} \mathrm{C}$. This correlates well with the activation threshold temperature of polymodal nociceptors and of the nociceptor-specific heat transducer transient receptor potential vanilloid receptor 1 (TRPV1 $[9,10])$, a member of the thermoTRP family of ion channels $[11,12]$. Nonetheless, nociceptors lacking TRPV1 have normal heat responses [13] and TRPV channel block with ruthenium red did not affect heat sensitivity of mechano-heat sensitive (polymodal) nociceptors, the most common nociceptor type, in vitro [14]. Other heat-sensitive ion channels must therefore be responsible for physiological transduction of heat stimuli. Thermosensitive TRPA1 so far has been found sensitive to cold stimuli (McKemy et al., 2002;Story et al., 2003), but possible candidates may be other members of the TRP superfamiliy, e.g. members of the TRPC subfamily which are also expressed in nociceptors [15-17]. The TRPC1 and TRPC6 ion channels co-operate with TRPV4 and may thus mediate mechanical hyperalgesia and nociceptor sensitization. However, it is well established that the capsaicin receptor TRPV1 is essential for the development of inflammatory hypersensitivity to heat stimuli in mice $[18$, 19]. The sensitivity of TRPV1 to heat and capsaicin depends 
on the phosphorylation status of the channel at intracellular serine/threonine or tyrosine sites [20-22] and this is regulated by a variety of inflammatory mediators including cytokines and chemokines (for review see [23, 24]). Intracellular signalling cascades are diverse but frequently converge on the activation of protein kinases (Fig. 1). Specific phosphorylation sites within TRPV1 intracellular sequence domains have been identified for PKC isoforms which are essential regulators of ion channel function and trafficking ([25-28] and see also the chapter of Camprubi-Robles and co-authors in this issue). Protein kinases of the PKA or CaMK type may share these phosphorylation sites and regulate TRPV1 [29-33] and even crosstalk between different arms of the signalling pathways may be relevant, however, are to date not fully understood. Nonetheless, drugs targeting TRPV1 are considered promising novel analgesics [23, 34].

The enigma of "the" nociceptor specific mechanosensitive ion channel so far has not unequivocally been resolved although a number of mechanosensitive ion channels has been identified (for review see [35]. Regarding the molecular correlates of mechano-nociceptor sensitivity several ion channels including members of the degenerin/ASIC family or the TRP family have been discussed as possible mechanosensors (for review [36-38]). While some of the ASIC channels have been excluded as relevant channels for mechanical nociceptive transduction [39], some of the TRP channels expressed in nociceptive primary afferents are currently analysed by several groups. Recent data suggest a role in the detection of noxious mechanical stimuli for TRPA 1 $[40,41]$ which is also a potential target for modulation by chemokines and cytokines [42]. The TRPV4 channel may also contribute to the development of mechanical hyperalgesia of diverse etiologies, presumably as part of a mechanoreceptor signalling complex [43, 44]. It interacts with cytoskeletal components and members of the TRPC subfamily and is inhibited by the stretch-activated channel (SACs) inhibitor GsMTX-4. Intradermal injection of GsMTX-4 into the rat hind paw reversed mechanical hypersensitivity induced by intradermal injection of inflammatory mediators. In addition, single fibre recordings showed that GsMTx-4 reversed inflammatory mediator-induced decrease in mechanical threshold in half of sensitized C-fibres. Furthermore, GsMTx-4 reduced hypersensitivity to both mechanical stimuli in models of inflammatory and neuropathic pain, but did not affect baseline mechanical nociceptive thresholds [4345]. Therefore, TRPV4 may be relevant for mechanical hypersensitivity. Lastly, TRPC1, and TRPC6 are expressed in DRG neurons $[15,45,46]$ and antisense RNAi to TRPC6, but not to TRPC1, reversed the mechanical hyperalgesia

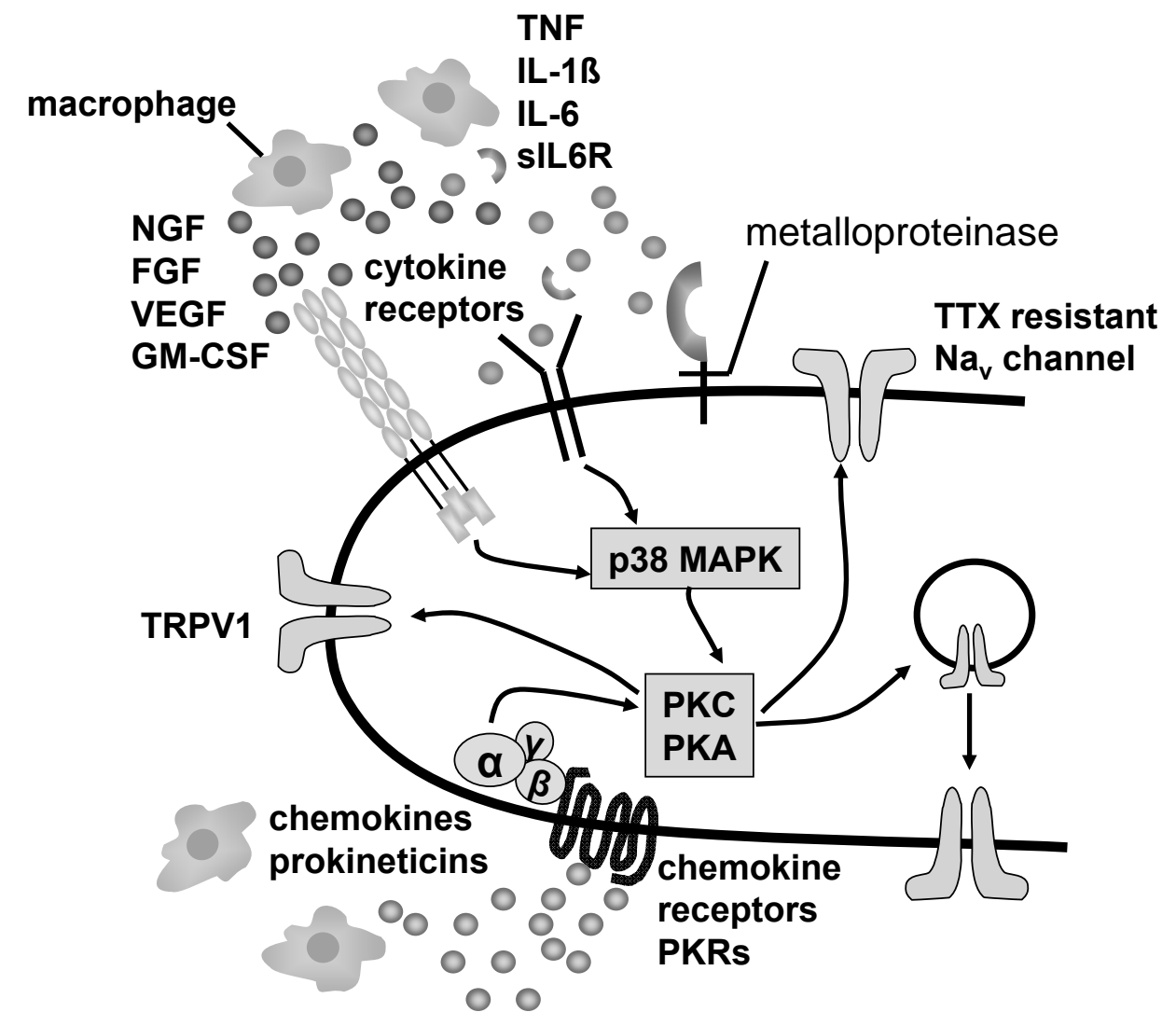

Fig. (1). Cytokines bind specific membrane receptors to regulate nociceptive ion channels in primary afferent nociceptors. Macrophages release cytokines, chemokines or growth factors which bind to membrane receptors or soluble receptors. Intracellular signalling cascades involving protein kinases phosphorylate ion channels and increase neuron excitability or sensitivity for natural stimuli. NGF: Nerve growth factor, FGF: fibroblast growth factor: VEGF: vascular endothelial derived growth factor, GM-CSF: granulocyte macrophage colonystimulating factor, TNF $\alpha$ : tumour necrosis factor $\alpha$, IL-1ß: interleukin-1ß, IL-6: interleukin-6, sIL-6R: soluble IL-6 receptor, TTX: tetrodotoxin, TRPV1: transient receptor potential vanilloid 1 receptor channel, PKR: prokineticin receptor, p38 MAPK: p38 mitogenactivated protein kinase, PKA: protein kinase A, PKC: protein kinase C. 
induced by a thermal injury. TRPC1 and TRPC6 channels may cooperate with TRPV channels to mediate mechanical nociceptor sensitization [45].

\section{HYPERALGESIAS ASSOCIATED WITH PAIN STATES WITH INFLAMMATORY COMPONENT}

While acute pain serves as an essential alarm system to protect our body's integrity, tissue injury including inflammation, nerve lesion and cancer generate pathological pain states characterised by mechanical and/or thermal (heat, cold) hyperalgesia and/or allodynia in humans. A number of animal models have been developed to study the associated changes within the nociceptive system [47] and investigate peripheral mechanisms of thermal and mechanical hypersensitivity [48]. Proinflammatory mediators which signal inflammation have been found to sensitize or excite nociceptors and cause hypersensitivity in animal models [7, 49-53]. Many of the findings obtained on nociceptor pathophysiology from animal models are translated into human pain models (for review see [54]). Regarding neuroimmune interactions, cytokines have emerged as the most important link between the immune system and nociception. Since the first report on the interferons $[55,56]$ the cytokine family has gained a considerable number of new members. Among the cytokine gene products associated with proinflammatory and proalgesic effects are several families including TNF and members of its superfamily, IL-1alpha, IL-1beta, IL-6, IL-8, IL-15, IL-18, IL-33 and the more recently discovered chemotactic cytokines (chemokines).

\section{NEUROIMMUNE COMMUNICATION USING CY- TOKINES AND CHEMOKINES}

In general, cytokines are small proteins with a molecular mass lower than $30 \mathrm{kDa}$. They are produced and secreted on demand, have a short life span and only travel over short distances if not released into the blood circulation. In vivo concentrations are in the range of a few pg to ng per $\mathrm{ml}$. They bind specifically to receptor molecules on the cell surface with binding constants between $10^{-12}$ and $10^{-10} \mathrm{M}$. Cytokines are a chemically diverse group of proteins but share common functions as regulators in the immune system. In addition to the classical interleukins and the chemotactic chemokines, growth factors like VEGF or FGF and the colony stimulating factors are also considered cytokines since they have pleiotropic actions and regulatory function in the immune system. Some cytokines and cytokine receptors are shedded by metalloproteinases (see below) which are also briefly reviewed in this article since they regulate cytokines and cytokine receptors in inflammation and cancer [57-59]. Despite the redundancy and pleiotropy of the cytokine network, specific actions of individual cytokines and endogenous control mechanisms have been identified. Particular local profiles of the classical proinflammatory cytokines are associated with inflammatory hypersensitivity and suggest an early involvement of TNF $\alpha$, IL- $1 \beta$ and IL-6 [60-62]. Moreover, an increasing number of further proinflammatory cytokines and the more recently discovered chemokines are associated with pathological pain [63-66]. Besides acting as inflammatory mediators increasing evidence indicates that cytokines act on nociceptors [65, 67] where they specifically interact with neuronal receptors and ion channels regulating neuronal excitability, sensitivity to external stimuli and synaptic plasticity [67].

\section{Tumour Necrosis Factor TNFa}

TNF $\alpha$ initiates the activation cascade of cytokines, chemokines and growth factors in the inflammatory response and therefore is generally accepted as the prototypic proinflammatory cytokine. Converging evidence points to a strong correlation between the number of macrophages, the level of TNF $\alpha$ production and the development of heathyperalgesia in inflammatory and neuropathic animal models $[68,69]$. Moreover, histology of experimental tumours shows a pronounced infiltration of the neoplastic tissue with macrophages and immune cells producing TNF $\alpha$ [70-72]. The TNF $\alpha$ antagonist etanercept ${ }^{\mathbb{B}}$ attenuates nociceptor sensitzation and heat and mechanical hypersensitivity in rodent cancer model [70, 73]. TNF $\alpha$ is accordingly synthesized and released in tumour tissue and induces heat hypersensitivity and pain by directly affecting nociceptors innervating the tumour area. Therefore, it is not surprising that, anti-TNF $\alpha$ treatment of refractory pain in selected pain patients significantly improved pain scores [74, 75]. Lastly, there is a strong link for TNF to the generation and maintenance of neuropathic pain [69, 76-79]. In animal models, injection of TNF induces mechanical and thermal hypersensitivity $[70,80,81]$. TNF seems to affect nociceptors directly, since sensitization of cutaneous nociceptors to heat also occurs in vitro at physiological $\mathrm{pH}$ which largely excludes secondary effects $[70,82,83]$. TNF $\alpha$ elicits neuronal discharges in dorsal root ganglion (DRG) neurons, and injured as well as neighboring uninjured afferent neurons exhibit an increased sensitivity to TNF [84]. TNF $\alpha$ binds to TNF receptor 1 (TNFR1) and TNF receptor 2 (TNFR2) in the cell membrane. Both receptor subtypes are expressed by primary afferent nociceptors [70, 85] and upregulated following experimental nerve lesion or inflammation $[68,83,85]$. While neuropathic pain largely seems to depend on TNF $\alpha$ TNFR1 [85-90] TNFR2 seems to be more relevant for the development of cancer-induced heat pain and hyperalgesia since upregulation of TRPV1 and heat hypersensitivity is found in wild type but not in TNFR2-/mice with experimental cancer [70].

Downstream of its receptors $\mathrm{TNF} \alpha$ activates protein kinases including mitogen activated kinase $\mathbf{p 3 8} \boldsymbol{M} \boldsymbol{M A P K}$ and $P K C$ [91]. TNF-induced hypersensitivity to heat is mediated via p38 MAPK [92-94] and TNF $\alpha$ induces a fast sensitization of responses to both heat and the specific TRPV1 agonist capsaicin which requires activation of $\mathrm{p} 38$ /MAP kinase and PKC [70]. Although PKC phosphorylates TRPV1 at specific sites and regulates channel function [95-97] some of the phosphorylation sites of the TRPV1 channel protein do not show preference for PKC, PKA or CaMKII and could be possible targets for phosphorylation by p38/MAPK [29, 30, 98-100]. Besides regulating TRPV1 channel function at the cell membrane, TNF $\alpha$ also induces up-regulation of TRPV1 expression [101]. Both mechanisms cooperate to sensitize nociceptors to heat. To provide nociceptors with even greater capacity to generate facilitated responses, cytokines also regulate nociceptor excitability (for review see [102]). TNF increases nociceptor excitability in a dual mode of action. First, via p38 activation it enhances TTX-resistant sodium currents which are a critical site of modulation underlying 
hypersensitivity [103] and second, TNF suppresses sustained potassium currents which regulate membrane potential [104]. Both effects leave the nociceptive neuron in a hyperexcitable state and increase the probability of action potential firing following an increased generator potential by TNF $\alpha$.

\section{Interleukin-1 13}

Inflammation induces hypernociception that is mediated by an initial release of TNF- $\alpha$ which triggers the subsequent release of IL-1ß $[105,106]$. IL-1 $1 \beta$ is the most studied member of the expanding IL-1 family because of its role in mediating autoinflammatory diseases (reviewed in [107]). More than any other cytokine family, the interleukin-1 (IL-1) family is closely linked to the innate immunity response [108]. The IL-1 family consists of two major agonistic proteins, IL- $1 \alpha$ and IL-1ß, which are pleiotropic and affect mainly inflammation, immunity, and hemopoiesis. In their secreted form, IL- $1 \alpha$ and IL- $1 \beta$ bind to the same receptors and induce the same biological function but differ in their compartmentalization within the producing cell or the microenvironment. Thus, IL-1ß is solely active in its secreted form, whereas IL-1 $\alpha$ is mainly active in cellassociated forms (for review see [109]). Major cellular sources for IL-1ß in the context of pain include macrophages, glial cells and both sympathetic and sensory neurons $[63,110,111]$. Inflammatory hyperalgesia can be prevented by experimental administration of endogenous IL1 receptor antagonist (IL-1 ra), and pain-associated behavior in mice with experimental neuropathy is reduced by neutralizing antibodies to IL-1 receptors $[105,112]$. IL-1 $\beta$ levels are locally increased in mice with experimental tumours. Osteosarcoma-induced thermal and mechanical hyperalgesia is inhibited by high doses of systemic anakinra, a neutralizing anti-IL1 $\beta$ antibody but not when anakinra is given intrathecally. This suggests that some hyperalgesic symptoms observed in the mouse model of bone cancer pain are mediated by peripheral IL-1ß induced nociceptor sensitization and may be inhibited by antagonists of IL-1 receptors type I [113]. However, the reduced mechanical hypersensitivity following treatment with exogenously given IL-1ra, the naturally occurring soluble IL-1 decoy receptor, is mainly explained by regulation of spinal nociceptive processing by IL-1ß [114-116]. Local injection of IL-1 $\beta$ induces pain reflexes which might occur due to a secondary increase in prostaglandins [117].The peripheral pronociceptive IL-1 action is likely mediated by a complex intracellular signalling cascade and secondary production of nitric oxide, bradykinin or prostaglandins by which sensitization or excitation of nociceptors may be explained [118122]. Expression of IL-1 receptor type I (IL-1RI) mRNA in sensory neurons suggests a possible direct influence of IL-1 $\beta$ on sensory processing $[110,123]$. IL-1 $\beta$ facilitates heatevoked release of calcitonin gene-related peptide [82] and sensitizes heat-activated inward currents $\left(\mathrm{I}_{\text {heat }}\right)$ in sensory neurons via PKC and tyrosine kinases [123]. In addition, IL$1 \beta$ acts in a p38 MAP kinase-dependent manner, to increase the excitability of nociceptors by regulating TTX-resistant voltage-gated sodium channels [124]. IL-1ß induced pain hypersensitivity is largely reduced in mice carrying a null mutation for the voltage-gated sodium channel Nav1.9 [125]. In addition, IL-1 $1 \beta$ induced activation of $\mathrm{c}-\mathrm{Src}$ kinase regulates preprotachykinin gene expression in rat sensory ganglia and substance P (SP) secretion [126]. Both, IL-1 $\alpha$ and IL- $1 \beta$ increase the neuronal content of SP. Interestingly, IL- $1 \alpha$ was significantly more efficient than IL- $1 \beta$ in inducing SP expression [127]. Taken together, all data suggest that IL- $\beta$ has a significant role in peripheral nociceptor sensitization which similar to TNF $\alpha$ converges on TRPV1 regulation whereas mechanical hypersensitivity mainly depends on indirect signalling pathways.

\section{Interleukin-6}

The classical proinflammatory IL-6 is an important neuronal survival and neurite elongation factor [128-132] and neurons including nociceptors express signal transducer components present at the cell membrane [133, 134]. IL-6 is produced and excreted by immune cells including macrophages, glia cells and even neurons (reviewed in [135]). Increased levels of IL-6 have been correlated with sickness behaviour in humans [136] and treatment associated symptoms like pain, fatigue and others [137]. Apart from controlling immune cell interactions, IL-6 may account for the pain and hypersensitivity associated with inflammation, neuropathy or cancer by directly regulating the gain of pain-sensing neurons. IL-6-/- mice present with reduced thermal hyperalgesia after carrageenan inflammation or nerve constriction [138-140]. Antisera neutralizing endogenous IL6 inhibit inflammatory hyperalgesia [141]. In neuropathic mice, nerve injury correlates well with upregulated IL-6 levels and development of thermal hyperalgesia and allodynia $[138,142,143]$. Some tumours produce interleukin-6 [144] and elevation of serum IL-6 levels is found in up to $60 \%$ of lung cancer patients in advanced stages [145]. Mice with a selective deletion of the signal transducer protein gp130 in neurons develop significantly reduced levels of inflammatory and tumour-induced pain independent of the degree of inflammation or tumour growth [146]. In addition, IL-6 sensitises peripheral nociceptors to mechanical stimuli [147]. Both peripheral as well as central sites of action may also be relevant for the side effects of cancer chemotherapy which may increase plasma levels of IL-6 [148]. IL-6, although involved in the generation of neuropathic pain states [149], may on the other hand protect against chemotherapy induced neuropathies without impairing anti-tumoural activity of the anti-mitotic drugs [150] and therefore global neutralization of IL-6 signalling is controversially discussed. However, most experimental studies report proinflammatory and pro-nociceptive roles for IL-6 [142, 151, $152]$. In most systems including sympathetic neurons, IL-6 effects depend on the presence of the soluble IL-6 receptor (sIL-6R) [129] which after ligand binding heteromerizes with the signal transducer molecule gp130 that is also utilized by other cytokines of the same family, e.g. LIF [153, 154]. IL-6/sIL-6R complex or Hyper-IL-6 (HIL-6), a fusion protein mimicking the effects of the IL-6/sIL-6R complex $[128,155]$, increase nociceptor responsiveness and induce thermal hypersensitivity $[82,134,156]$. A dual regulation of heat sensitivity by IL-6 and its soluble receptor sIL-6R has been reported [156]. The sensitization involves activation of the Janus tyrosine kinase (Jak), the adapter proteins Gab1 and Gab2 and finally PKC-delta which regulates the heat transducer ion channel TRPV1 [134, 146]. Currently, the launch of inhibitors IL-6 or gp130 as a novel class of antiinflammatory drugs not only gives rise to great hopes for the 
treatment of inflammation in rheumatoid arthritis [157-159] but may also alleviate its most quality of life worsening symptom, pain.

\section{OTHER PROINFLAMMATORY CYTOKINES}

\section{Colony-Stimulating Factors}

Granulocyte- and granulocyte-macrophage colonystimulating factors $(\boldsymbol{G}-\boldsymbol{C S} \boldsymbol{F}$ and $\boldsymbol{G M}-\boldsymbol{C S} \boldsymbol{F})$ were originally defined as haematopoietic-cell growth factors, but have also been shown to act directly on mature myeloid cells. Recent data from animal models indicate that the depletion of CSFs has therapeutic benefit in many inflammatory and/or autoimmune conditions. As a result, early-phase clinical trials targeting granulocyte/macrophage colony-stimulating factor and macrophage colony-stimulating factor have now commenced (reviewed in [160]. CSFs mediate tumour nerve interactions and bone cancer pain in a mouse model [161]. Local injection of GM-CSF causes hypersensitivity to mechanical and thermal stimuli and GM-CSF sensitizes nerves to mechanical stimuli and capsaicin in vitro and in vivo [161]. Specific membrane receptors are expressed and are functional on nociceptive afferents $[161,162]$ and inhibition of G-CSF and GM-CSF signalling in vivo reduces tumour growth and nerve remodeling, and abrogates bone cancer pain [161].

Although a number of other proinflammatory cytokines have recently been associated with hyperalgesia, we are just beginning to understand their role in regulating nociceptor sensitivity. Frequently, their mode of action is indirect via control of downstream immediators of inflammation which in turn may affect nociceptive primary afferent. Particularly for the development of mechanical inflammatory hypersensitivity a crucial role for leukocytes has been reported and more recently discovered leukocyte products like IL-15, IL-18, IL-33 and the chemokine CINC-1 have come into focus of pain researchers. These cytokines frequently trigger sequential release of interferon-gamma, endothelin and prostaglandins which in turn affect nociceptor phenotypes [163-166].

\section{Chemokines}

When tissue is invaded by immune cells chemokines are released as constituents of the inflammatory soup [167]. Chemokines are small chemotactic cytokines of about $10 \mathrm{kD}$ which are secreted in damaged tissue not only by leucocytes but also by activated glia cells or neurons. More than 45 chemokines have been identified and chemokine classification is based on the presence and position of cystein residues. The $\mathrm{CC}$ group has two cysteins next to each other, in the CXC group the two cystein residues are separated by one other amino acid, and the $\mathrm{CX} 3 \mathrm{C}$ chemokine $\mathrm{CX} 3 \mathrm{CL}$ (alias fractalkine) where the cysteins are separated by three other amino acid residues is the only member of its class [168]. Chemokine actions are mediated by seventransmembrane domain receptors that couple to the inhibitory G-protein $\mathrm{G}_{\mathrm{i}}$. Currently, nineteen chemokine receptors have been identified and they are expressed on a variety of cells, including immune cells, endothelial cells and neurons (for review see [169-172]). Chemokines promote immune cell migration, induce astrocyte migration and proliferation of microglia regulating nociceptive transmission in the spinal dorsal horn (for review see [167]. The chemokines CCL2 (and CXCL1) triggers calcitonin generelated peptide release by exciting nociceptive neurons [173, 174], and induces mechanical hyperalgesia after intradermal injection [175]. In addition, it functions as a neuromodulator in neuropathic pain $[175,176]$. The chemokine network is activated at multiple levels of the peripheral and central nervous system and has recently been identified as new target for pain relief [64]. Small molecule antagonists for particular chemokine receptors may therefore not only be promising for the treatment of acute and chronic inflammation $[170,177]$ but may also be of relevance in pain biology and therapy (for review see [64, 178].

\section{GROWTH FACTORS}

A number of growth factors have been associated with the development of nociceptor hypersensitivity; however, for many of them we are just beginning to understand their role in pathological pain.

Nerve growth factor (NGF) was originally identified as an essential neuronal survival factor in the developing nervous system. In adults, NGF has a crucial role in generating pain and hyperalgesia. The expression of NGF is high in inflamed tissue and anti-NGF treatment provides effective pain control in animal models of inflammatory pain (for review see [179]. NGF and NGF receptor expression are high in immune cells and certain types of cancer [180-182] and more recently, crosstalk between NGF and TNF $\alpha$ has been associated with painful diseases, however, is not yet fully understood (for review see [183]). In inflammatory pain animals models, NGF is involved in thermal hyperalgesia and nociceptor sensitization $[184,185]$ and neutralization of NGF improves bone cancer pain and reduces up-regulation of ATF3 and other biochemical markers of nociceptor activation [186, 187]. NGF sensitizes nociceptive neurons to heat and capsaicin by binding to specific neurotrophin receptors activating PI3 and p38/MAP kinase dependent pathways [188] and rapidly increases TRPV1 expression in the nociceptor membrane [26, 27, 92]. Several pharmaceutical companies have developed approaches to antagonize NGF including NGF capture blocking the binding to its receptors, and NGF antagonism is expected to provide effective treatment for chronic pain states [179, 189].

Prokineticins PK1 (vascular endothelia growth factor, $\boldsymbol{V E G F}$ ) and $\boldsymbol{P K} \mathbf{2}$ are tissue-specific angiogenic factors which share certain aspects of cytokines: PKs are highly expressed by neutrophils and other inflammatory cells and play a role in immune-inflammatory responses. PK-like hyperalgesic activity was demonstrated in extracts of rat inflammatory granulocytes and PKs seem to be new pronociceptive mediators in inflammatory tissues (for review [190]). VEGF/PK1 is significantly elevated in cancer patients [191] and it is secreted by islets and stellate cells in pancreatic cancer [192]. Nociceptors express prokineticin receptors PKR1 and PKR2 under the control of glia derived neurotrophic factor GDNF. The receptors for prokineticins are present in a fraction of peptidergic $\mathrm{C}$-fibre neurons and in a fraction of myelinated A fiber neurons. PKR-expressing neurons also express TRPV1, and Bv8, an agonist oft both PKR1 and PKR2, has recently been shown to sensitize 
TRPV1 channels [193]. Intraplantar injection of recombinant PK2 results in a strong and localized hyperalgesia with reduced thresholds to nociceptive stimuli. PK2 mobilizes calcium in dissociated dorsal root ganglion (DRG) neurons and mice lacking the PK2 gene display strong reduction in thermal and chemical nociception. However, PK2 mutant mice showed no difference in inflammatory response to capsaicin [194]. Mice lacking the PKR1 gene exhibit impaired Bv8-induced hyperalgesia, develop deficient responses to noxious heat, capsaicin and protons and show reduced thermal and mechanical hypersensitivity to paw inflammation, indicating a requirement for PKR1 signalling associated with activation and sensitization of primary afferent fibres [195]. This may also be the case for other growth factors including fibroblast growth factor [196] which has pleiotropic effects and at the same time may regulate nociception and pain sensation [197].

\section{METALLOPROTEASES}

Matrix Metalloproteases (MMP) are a family of enzymes which contribute to the degradation of the extracellular matrix and this is generally accepted to regulate leukocyte migration, inflammation, and wound healing [58, 198]. MMPs function as regulators of entire groups of cytokines and their downstream signalling pathways since they determine the degree of cytokine receptor activation by shedding of membrane bound receptor proteins or of target proteins relevant for nociceptor or immune cell function [199]. Studies propose the involvement of matrix metalloproteinases $M M P-1,-2,-3,-9,-13$ and $A D A M-$ $17(T A C E)$ and ADAMTS5 as major in vivo mediators of extracellular matrix degradation $[200,201]$. They represent promising therapeutic targets to treat ostheoarthritic symptoms and more selective inhibitors are currently developed (for review see [202]). MMPs are also emerging as modulators of neuropathic pain [203-205]. Up-regulation of MMP-3 and following macrophage activation caused in the dorsal root ganglion found in animal models of neuropathic pain might be a significant event to trigger a series of reactions occuring along primary nociceptive afferents after nerve lesion [206]. Although little evidence is available for a direct role of MMPs at peripheral nociceptors, MMP inhibitors could be potentially interesting for pain therapy induced by inflammation and nerve lesion since they can control cytokine and chemokine substrates in health and disease. A significant role for MMPs is emerging for neuropathic pain $[192,207,208]$ but cleavage of specific substrates and transsignalling by MMPs may be a more general mechanism for regulating nociceptor sensitivity by MMPs.

\section{CONCLUSION AND OUTLOOK}

Severe pain persists in many patients even with high dose analgesic therapies. Individual variations in the severity of pain and in the responsiveness to treatment have been assumed to result from either sociodemographic characteristics (age, sex, race, marital status), clinical health status (performance status, comorbid conditions) or disease-related variables (stage of disease). Cytokines are strongly linked to inflammation, neuropathy and cancer and there is increasing evidence that the balance between proalgesic and antialgesic cytokines is relevant for the severity and persistence of the accompanying pain $[209,210]$. Understanding the molecular epidemiology of pathological pain offers the opportunity of identifying specific genes involved in the cytokine network that could be used for a more personalized treatment of pain. A first step towards a more mechanistic pain therapeutic strategy could be avoidance of generation of hypersensitive pain processing by either neutralization strategies in order to prevent triggering the proinflammatory cytokine avalanche or by shifting the cytokine balance in favour of antiinflammatory cytokines.

\section{REFERENCES}

[1] Andrew D, Greenspan JD. Mechanical and heat sensitization of cutaneous nociceptors after peripheral inflammation in the rat. $\mathbf{J}$ Neurophysiol 1999; 82: 2649-56.

[2] Burgess PR, Perl ER. Myelinated afferent fibres responding specifically to noxious stimulation of the skin. J Physiol 1967; 190: 541-62.

[3] Kress M, Koltzenburg M, Reeh PW, Handwerker HO. Responsiveness and functional attributes of electrically localized terminals of cutaneous C-Fibers in vivo and in vitro. J. Neurophysiol 1992; 68: 581-595.

[4] Koltzenburg M, Stucky CL, Lewin GR. Receptive properties of mouse sensory neurons innervating hairy skin. J Neurophysiol 1997; 78: 1841-50.

[5] Schmidt R, Schmelz M, Forster C, Ringkamp M, Torebjork HE, Handwerker HO. Novel classes of responsive and unresponsive C nociceptors in human skin. J Neurosci 1995; 15: 334-41.

[6] Zimmermann K, Hein A, Hager U, et al. Phenotyping sensory nerve endings in vitro in the mouse. Nat Prot 2009; 4: 174-96.

[7] Lang E, Novak A, Reeh PW, Handwerker HO. Chemosensitivity of fine afferents from rat skin in vitro. J Neurophysiol 1990; 63: 887901.

[8] Schmelz M, Schmidt R, Weidner C, Hilliges M, Torebjork HE, Handwerker HO. Chemical response pattern of different classes of C-nociceptors to pruritogens and algogens. J Neurophysiol 2003; 89: 2441-8.

[9] Caterina MJ, Schumacher MA, Tominaga M, Rosen TA, Levine JD, Julius D. The capsaicin receptor: a heat-activated ion channel in the pain pathway. Nature 1997; 389: 816-24.

[10] Tominaga M, Caterina MJ, Malmberg AB, et al. The cloned capsaicin receptor integrates multiple pain-producing stimuli. Neuron 1998; 21: 531-43.

[11] Jordt SE, McKemy DD, Julius D. Lessons from peppers and peppermint: the molecular logic of thermosensation. Curr Opin Neurobiol 2003; 13: 487-92.

[12] Talavera K, Nilius B, Voets T. Neuronal TRP channels: thermometers, pathfinders and life-savers. Trends Neurosci 2008; 31: 287-95

[13] Woodbury CJ, Zwick M, Wang S, et al. Nociceptors lacking TRPV1 and TRPV2 have normal heat responses. J Neurosci 2004; 24: 6410-5.

[14] St.Pierre M, Reeh PW, Zimmermann K. Differential effects of TRPV channel block on polymodal activation of rat cutaneous nociceptors in vitro. Exp Brain Res 2009; 196: 31-44.

[15] Kress M, Karasek J, Ferrer-Montiel AV, Scherbakov N, Haberberger RV. TRPC channels and diacylglycerol dependent calcuim signaling in rat sensory neurons. Histochem Cell Biol 2008; 130: 655-67.

[16] McKemy DD, Neuhausser WM, Julius D. Identification of a cold receptor reveals a general role for TRP channels in thermosensation. Nature 2002; 416: 52-8.

[17] Story GM, Peier AM, Reeve AJ, et al. ANKTM1, a TRP-like channel expressed in nociceptive neurons, is activated by cold temperatures. Cell 2003; 112: 819-29.

[18] Davis JB, Gray J, Gunthorpe MJ, et al. Vanilloid receptor-1 is essential for inflammatory thermal hyperalgesia. Nature 2000; 405 : 183-7.

[19] Chuang HH, Prescott ED, Kong H, et al. Bradykinin and nerve growth factor release the capsaicin receptor from PtdIns[4,5]P2mediated inhibition. Nature 2001; 411: 957-62.

[20] Bhave G, Zhu W, Wang H, Brasier DJ, Oxford GS, Gereau RW. cAMP-dependent protein kinase regulates desensitization of the 
capsaicin receptor [VR1] by direct phosphorylation. Neuron 2002; 35[4]: 721-31.

[21] Rathee PK, Distler C, Obreja O, et al. PKA/AKAP/VR-1 module: A common link of Gs-mediated signaling to thermal hyperalgesia. J Neurosci 2002; 22: 4740-5.

[22] Mandadi S, Tominaga T, Numazaki M, et al. Increased sensitivity of desensitized TRPV1 by PMA occurs through PKCepsilonmediated phosphorylation at S800. Pain 2006; 123: 106-16.

[23] Patapoutian A, Tate S, Woolf CJ. Transient receptor potential channels: targeting pain at the source. Nat Rev Drug Discov 2009; 8: $55-68$.

[24] Zhang N, Oppenheim JJ. Crosstalk between chemokines and neuronal receptors bridges immune and nervous system. J Leukoc Biol 2005; 78: 1210-4.

[25] Morenilla-Palao C, Planells-Cases R, Garcia-Sanz N, FerrerMontiel A. Regulated exocytosis contributes to protein kinase C potentiation of vanilloid receptor activity. J Biol Chem 2004; 279 : 25665-72.

[26] Zhang X, Huang J, McNaughton PA. NGF rapidly increases membrane expression of TRPV1 heat-gated ion channels. EMBO J 2005; 24: 4211-23.

[27] Stein AT, Ufret-Vincenty CA, Hua L, Santana LF, Gordon SE. Phosphoinosite 3-kinase binds to TRPV1 and mediates NGFstimulated TRPV1 trafficking to the plasma membrane. J Gen Physiol 2006; 128: 509-22.

[28] Camprubí-Robles M, Planells-Cases R, Ferrer-Montiel A. Differential contribution of SNARE-dependent exocytosis to inflammatory potentiationof TRPV1 in nociceptors. FASEB J 2009; 23(1): 3722-33.

[29] Mohapatra DP, Nau C. Desensitization of capsaicin-activated currents in the Vanilloid receptor TRPV1 is decreased by the cyclic AMP-dependent protein kinase pathway. J Biol Chem 2003; 278: 50080-90.

[30] Rathee PK, Distler C, Obreja O, et al. PKA/AKAP/VR-1 module: a common link of Gs-mediated signaling to thermal hyperalgesia. J Neurosci 2002; 22: 4740-5.

[31] Zhang X, Li L, McNaughton PA. Proinflammatory mediators modulate the heat-activated ion channel TRPV1 via the scaffolding protein AKAP79/150. Neuron 2008; 59: 450-61.

[32] Bonnington JK, McNaughton PA. Signalling pathways involved in the sensitisation of mouse nociceptive neurones by nerve growth factor. J Physiol 2003; 551: 433-46.

[33] Schnizler K, Shutov LP, Van Kanegan MJ, et al. Protein kinase A anchoring via AKAP150 is essen tial for TRPV1 modulation by forskolin and prostaglandin E2 in mouse sensory neurons. J Neurosci 2008; 28: 4904-17.

[34] Szallasi A, Cortright DM, Blum CA, Eid SR. The vanilloid receptor TRPV1: 10 years from channel cloning to antagonist proof-of-concept. Nat Rev Drug Discov 2007; 6: 357-72.

[35] Bowman CL, Gottlieb PA, Suchnya TM, Murphy YK, Sachs F. Mechanosensitive ion channels and the peptide inhibitor GsMTx-4: history, properties, mechanisms and pharmacology. Toxicon 2007; 49: 249-70.

[36] Lumpkin Ea, Caterina MJ. Mechanisms of sensory transduction in the skin. Nature 2007; 445: 858-65.

[37] Christensen AP, Corey DP. TRP channels in mechanosensation: direct or indirect activation? Nat Rev Neurosci 2007; 8: 510-21.

[38] Lumpkin EA, Bautista DM. Feeling the pressure in mammalian somatosensation. Curr Opin Neurobiol 2005; 15: 382-8.

[39] Roza C, Puel J, Kress M, et al. Knockout of the ASIC2 channel in mice does not impair cutaneous mechanosensation, visceral mechanonociception and hearing. J Physiol 2004; 558: 659-69.

[40] Kerstein PC, del Camino D, Moran MM, Stucky CL. Pharmacological blockade of TRPA1 inhibits mechanical firing in nociceptors. Mol Pain 2009; 5: 19-32.

[41] Kwan KY, Glazer JM, Corey DP, Rice FL, Stucky CL. TRPA1 modulates mechanotransduction in cutanous sensory neurons. J Neurosci 2009; 29: 4808-19.

[42] White FA, Wilson NM. Chemokines as pain mediators and modulators. Curr Opin Anaesthesiol 2008; 21: 580-5.

[43] Alessandri-Haber N, Dina OA, Joseph EK, Reichling D, Levine JD. A transient receptor vanilloid 4-dependent mechanism of hyperalgesia is engaged by concerted action of inflammatory mediators. J Neurosci 2006; 26: 3864-74.

[44] Alessandri-Haber N, Dina OA, Joseph EK, Reichling DB, Levine JD. Interaction of transient receptor potential vanilloid 4, integrin, and SRC tyrosine kinase in mechanical hyperalgesia. J Neurosci 2008; 28: 1046-57.

[45] Alessandri-Haber N, Dina OA, Chen X, Levine JD. TRPC1 and TRPC6 channels cooperate with TRPV4 to mediate mechanical hyperalgesia and nociceptor sensitization. J Neurosci 2009; 29: 6217-28

[46] Elg S, Marmigere FC, Mattsson JP, Ernfors P. Cellular subtype distribution and developmental regulation of TRPC channel members in the mouse dorsal root ganglion. J Comp Neurol 2007; 503: $35-46$

[47] Sandkühler J. Models and mechanisms of hyperalgesia and allodynia. Physiol Rev 2009; 89: 707-58.

[48] Coutaux A, Adam F, Willer J-C, Le Bars D. Hyperalgesia and allodynia: peripheral mechanisms. Joint Bone Spine 2005; 72: 35971.

[49] Keele CA, Armstrong D. Substances producing pain and Itch. In: Barcroft H, Davson H, Paton WDM, Eds. London: Edward Arnold, Monographs of the Physiological Society 1964; Vol. 12.

[50] Handwerker HO, Ringkamp M, Schmelz M. Neurophysiological basis for chemogenic pain and itch. In: Boivie J, Hansson P, Lindblom U, Eds. Touch, Temperature and Pain in Health and Disease. Wenner-Gren International Symposium. Seattle: IASP Publications 1994; vol. 3; pp. 195-206.

[51] Schaible H-G, Schmidt RF. Effects of an experimental arthritis on the sensory properties of fine articular afferent units. J Neurophysiol 1985; 54: 1109-22.

[52] Schepelmann K, Messlinger K, Schaible HG, Schmidt RF Inflammatory mediators and nociception in the joint - excitation and sensitization of slowly conducting afferent-fibers of cats knee by prostaglandin I2. Neuroscience 1992; 50: 237-47.

[53] Julius D, Basbaum AI. Molecular mechanisms of nociception Nature 2001; 413: 203-10.

[54] Schmelz M. Translating nociceptive processing into human pain models. Exp Brain Res 2009; 196: 173-8.

[55] Isaacs A, Lindenmann J. Virus interference. I. The interferon. Proc R Soc Lond B Biol Sci 1957; 147: 258-67.

[56] Isaacs A, Lindenmann J, Valentine RC. Virus interference. II. Some properties of interferon. Proc R Soc Lond B Biol Sci 1957; 147: 268-73

[57] Huang SC, Sheu BC, Chang WC, Cheng CY, Wang PH, Lin S. Extracellular matrix proteases - cytokine regulation role in cancer and pregnancy. Front Biosci 2009; 14: 1571-88.

[58] Van Lint P, Libert C. Chemokine and cytokine processing by matrix metalloproteinases and its effect opn leukocyte migration and inflammation. J Leukoc Biol 2007; 82: 1375-81.

[59] Aggarwal BB, Shishodia S, Sandur SK, Pandey MK, Sethi G. Inflammation and cancer: how hot is the link? Biochem Pharmacol 2006; 72: 1605-21.

[60] Cunha TM, Verri WA Jr, Silva JS, Poole S, Cunha FQ, Ferreira $\mathrm{SH}$. A cascade of cytokines mediates mechanical inflammatory hypernociception in mice. Proc Natl Acad Sci USA 2005; 102: 1755-60.

[61] Loram LC, Fuller A, Fick LG, Cartmell T, Poole S, Mitchell D. Cytokine profiles during carrgeenan-induced inflammatory hyperalgesia in rat muscle and hind paw. J Pain 2007; 8: 127-36.

[62] Loram LC, Fuller A, Cartmell T, Mitchell B, Mitchell D Behavioural, histological and cytokine responses during hyperalgesia induced by carrageenan injection in the rat tail. Physiol Behav 2007; 92: 873-80.

[63] Watkins LR, Maier SF. Cytokines and pain. Basel: Birkhäuser 1999.

[64] Gosselin RD, Dansereau MA, Pohl M, et al. Chemokine network in teh nervous system: a new target for pain relief. Curr Med Chem 2008; 15: 2866-75

[65] Sommer C, Kress M. Recent findings on how proinflammatory cytokines cause pain: peripheral mechanisms in inflammatory and neuropathic hyperalgesia. Neurosci Lett 2004; 361: 184-7.

[66] Verri WA, Cunha TM, Parada CA, Poole S, Cunha FQ, Ferreira SH. Hypernociceptive role of cytokines and chemokines: Targets for analgesic drug development? Pharmac Ther 2006; 112: 116-38.

[67] Üceyler N, Schäfers M, Sommer C. Modeof action of cytokines on nociceptive neurons. Exp Brain Res 2009; 196: 67-78.

[68] Inglis JJ, Nissim A, Lees DM, Hunt SP, Chernajovsky Y, Kidd BL. The differential contribution of tumour necrosis factor to thermal and mechanical hyperalgesia during chronic inflammation. Arthritis Res Ther 2005; 7: R807-R816. 
[69] Sommer C, Schäfers M. Painful mononeuropathy in C57BL/Wld mice with delayed Wallerian degeneration: differential effects of cytokine production and nerve regeneration on thermal and mechanical hypersensitivity. Bain Res 1998; 784: 154-62.

[70] Constantin CE, Mair N, Sailer CA, et al. Endogenous necrosis factor alpha [TNFalpha] requires TNF receptor type 2 to generate heat hyperalgesia in a mouse cancer model. J Neurosci 2008; 28 : 5072-81.

[71] Mantyh PW, Hunt SP. Mechanisms that generate and maintain bone cancer pain. Novartis Found Symp 2004; 260: 221-38.

[72] Mantyh PW. Cancer pain and its impact on diagnosis, survival and quality of life. Nat Rev Neurosci 2006; 7: 797-809.

[73] Wacnik PW, Eikmeier LJ, Ruggles TR, et al. Functional interactions between tumor and peripheral nerve: morphology, algogen identification, and behavioral characterization of a new murine model of cancer pain. J Neurosci 2001; 21: 9355-66.

[74] Tobinick EL. Targeted etanercept for treatment-refractory pain due to bone metastasis: two case reports. Clin Ther 2003; 25: 2279-88.

[75] Tobinick EL, Davoodifar S. Efficacy of etanercept delivered by perispinal administration for chronic bck and/or neck disc-related pain: a study of clinical observations in 143 patients. Curr Med Res Opin 2004; 20: 1075-85.

[76] Sommer C, Lindenlaub T, Teuteberg P, Schäfers M, Hartung T, Toyka K. Anti-TNF-neutralizing antifbodies reduce pain-related behavior in two different mouse models of painful mononeuropathy. Brain Res 2001; 913: 86-9.

[77] Wagner R, Myers RR. Endoneurial injection of TNF-alpha produces neurpathic pain behaviors. Neuroreport 1997; 7: 2897901.

[78] Sorkin LS, Xiao WH, Wagner R, Myers RR. Tumor necrosis factor-alpha induces ectopic activity in nociceptive primary afferent fibres. Neuroscience 1997; 81: 255-63.

[79] Junger H, Sorkin LS. Nociceptive and inflammatory effects of subcutaneous TNF alpha. Pain 2000; 85: 145-51.

[80] Wacnik PW, Eikmeier LJ, Simone DA, Wilcox GL, Beitz AJ. Nociceptive characteristics of tumor necrosis factor-alpha in naive and tumor-bearing mice. Neuroscience 2005; 132: 479-91.

[81] Junger H, Sorkin LS. Nociceptive and inflammatory effects of subcutaneous TNFalpha. Pain 2000; 85: 145-51.

[82] Oprée A, Kress M. Involvement of the proinflammatory cytokines tumor necrosis factor- $\alpha$, IL- $1 \beta$ and IL-6 but not IL- 8 in the development of heat hyperalgesia: effects on heat-evoked calcitonin gene-related peptide release from rat skin. J Neurosci 2000; 20: 6289-93.

[83] Schäfers M, Sorkin LS, Geis C, Shubayev VI. Spinal nerve ligation induces transient upregulationof tumor necrosis factor receptors 1 and 2 in injured and adjacent uninjured dorsal root ganglia in the rat. Neurosci Lett 2003; 347: 179-82.

[84] Schäfers M, Lee DH, Brors D, Yaksh TL, Sorkin LS. Increased sensitivity of injured and adjacent uninjured rat primary sensory neurons to exogenous tumor necrosis factor-alpha after spinal nerve ligation. J Neurosci 2003; 23: 3028-38.

[85] Li Y, Ji A, Weihe E, Schäfer MK. Cell-specific expression and lipopolysaccharide-induced regulation of tumor necrosis factor alpha [TNFalpha] and TNF receptors in rat dorsal root ganglion. J Neurosci 2004; 24: 9623-31.

[86] Vogel C, Lindenlaub T, Tiegs G, Toyka KV, Sommer C. In: Painrelated behavior in TNF-receptor deficient mice. Devor $\mathrm{M}$, Rowbotham MC, Wiesenfeld-Hallin Z, Eds. Proceedings of the 9th World Congresson pain, progress in pain research and management Seattle: IASP Press 2000; pp. 249-57.

[87] Ohtori S, Takahashi K, Moriya H, Myers RR. TNF-alpha and TNFalpha receptor type 1 upregulation in glia and neurons after peripheral nerve injury: studies in murine DRG and spinal cord. Spine 2004; 29: 1082-8.

[88] Parada CA, Yeh JJ, Joseph EK, Levine JD. Tumor necrosis factor receptor type-1 in sensory neurons contributes to induction of chronic enhancement of inflammatory hyperalgesia in rat. Eur $\mathbf{J}$ Neurosci 2003; 17: 1847-52.

[89] Shubayev VI, Myers RR. Upregulation and interaction of TNFalpha and gelatinases $\mathrm{A}$ and $\mathrm{B}$ in painful peripheral nerve injury. Brain Res 2000; 855: 83-9.

[90] Scholz J, Woolf CJ. The neuropathic pain triad: neurons, immune cells and glia. Nat Neurosci 2007; 10: 1361-8.
[91] Vandenabeele P, Declercq W, Beyaert R, Fiers W. Two tumour necrosis factor receptors: structure and function. Trends Cell Biol 1995; 5: 392-9.

[92] Ji R, Samad T, Jin S, Schmoll R, Woolf C. p38 MAPK activation by NGF in primary sensory neurons after inflammation increases TRPV1 levels and maintains heat hyperalgesia. Neuron 2002; 36: 57-68.

[93] Milligan ED, Twining C, Chacur M, et al. Spinal glia and proinflammatory cytokines mediate mirror-image neuropathic pain in rats. J Neurosci 2003; 23: 1026-40.

[94] Schäfers M, Svensson CI, Sommer C, Sorkin LS. Tumor necrosis factor-alpha induces mechanical allodynia after spinal nerve ligation by activation of $\mathrm{p} 38$ MAPK in primary sensory neurons. $\mathrm{J}$ Neurosci 2003; 23: 2517-21.

[95] Numazaki M, Tominaga T, Toyooka H, Tominaga M. Direct phosphorylation of capsaicin receptor VR1 by protein kinase Cepsilon and identification of two target serine residues. J Biol Chem 2002; 277: 13378 .

[96] Vellani V, Mapplebeck S, Moriondo A, Davis JB, McNaughton PA. Protein kinase $\mathrm{C}$ activation potentiates gating of the vanilloid receptor VR-1 by capsaicin, protons, heat and anandamide. J Physiol 2001; 534: 813-25.

[97] Bhave $\mathrm{G}, \mathrm{Hu} \mathrm{HJ}$, Glauner $\mathrm{KS}$, et al. Protein kinase $\mathrm{C}$ phosphorylation sensitizes but does not activate the capsaicin receptor transient receptor potential vanilloid 1 [TRPV1]. Proc Natl Acad Sci USA 2003; 100: 12480-5.

[98] Caterina MJ, Schumacher MA, Tominaga M, Rosen TA, Levine JD, Julius D. The capsaicin receptor: a heat-activated ion channel in the pain pathway. Nature 1997; 389: 816-24.

[99] Price TJ, Jeske NA, Flores CM, Hargreaves KM. Pharmacological interactions between calcium/calmodulin-dependent kinase II alpha and TRPV1 receptors in rat trigeminal sensory neurons. Neurosci Lett 2005; 389: 94-8.

[100] Novakova-Tousova K, Vyklicky L, Susankova K, et al. Functional changes in the vanilloid receptor subtype 1 channel during and after acute desensitization. Neuroscience 2007; 149: 144-54.

[101] Khan AA, Diogenes A, Jeske NA, Henry MA, Akopian A, Hargreaves KM. Tumor necrosis factor alpha enhances the sensitivity of rat trigeminal neurons to capsaicin. Neuroscience 2008; 155: 503-9.

[102] Schäfers M, Sorkin LS. Effect of cytokines on neuronal excitability. Neursci Lett 2008; 437: 188-93.

[103] Jin X, Gereau RW4. Acute p38-mediated modulation of tetrodotoxin-resistant sodium channels in mouse sensory neurons by tumor necrosis factor- $\alpha$. J Neurosci 2006; 26: 246-55.

[104] Liu BG, Dobretsov M, Stimers JR, Zhang JM. Tumor necrosis factor- $\alpha$ suppresses sustained potassium currents in rat small diameter sensory neurons. Open Pain J 2008; 1: 01-7.

[105] Cunha TM, Verri WA Jr, Valério DA, et al. Role of cytokines in mediating mechanical hypernociception in a model of delayed-type hypersensitivity in mice. Eur J Pain 2008; 12: 1059-68.

[106] Dinarello CA, Cannon JG, Wolff S, et al. Tumor necrosis factor [cachectin] is an endogenous pyrogen and induces production of interleukin 1. J Exp Med 1986; 163: 1433-50.

[107] Barksby HE, Lea SR, Preshaw PM, Taylor JJ. The expanding family of interleukin-1 cytokines and their role in destructive inflammatory disorders. Clin Exp Immunol 2007; 149: 217-25.

[108] Dinarello CA. Immunological and inflammatory funcitons of the interleukin-1 family. Annu Rev Immunol 2009; 27: 519-50.

[109] Apte RN, Voronov E. Is interleukin-1 a good or bad 'guy' in tumor immunobiology and immunotherapy? Immunol Rev 2008; 222: 222-41.

[110] Copray JC, Mantingh I, Brouwer N, et al. Expression of interleukin-1beta in rat dorsal root ganglia. J Neuroimmunol 2001; 118: 203-11

[111] Freidin M, Bennett MV, Kessler JA. Cultured sympathetic neurons synthesized and release the cytokine interleukin-1beta. Proc Natl Acad Sci USA 1992; 89: 10440-3.

[112] Sommer C, Petrausch S, Lindenlaub T, Toyka K. Neutralizing antibodies to interleukin 1-receptor reduce pain associated behavior in mice with experimental neuropathy. Neurosci Lett 1999; 270: 25-8.

[113] Baamonde A, Curto-Reyes V, Juárez L, Meana A, Hidalgo A, Menéndez L. Antihyperalgesic effects induced by the IL-1 receptor antagonist anakinra and increased IL-1beta levels in inflamed and osteosarcoma-bearing mice. Life Sci 2007; 81: 673-82. 
[114] Zhang RX, Liu B, Wang L, et al. Interleukin $1 ß$ facilitates bone cancer pain in rats by enhancing NMDA receptor NR-1 subunit phosphorylation. Neurosci 2008; 154: 1533-8.

[115] Gustafson-Vickers SL, Lu VB, Lai AY, Todd KG, Ballanyi K, Smith PA. Long-term actions of interleukin-1beta on delay and tonic firing neurons in rat superficial dorsal horn and their relevance to central sensitization. Mol Pain 2008; 4: 63.

[116] Kleibeuker W, Gabay E, Kavelaars A, et al. IL-1 beta signaling is required for mechanical allodynia induced by nerve injury and for the ensuing reduction in spinal cord neuronal GRK2. Brain Behav Immun 2008; 22: 200-8.

[117] Schweizer A, Feige U, Fontana A, Müller K, Dinarello CA. Interleukin-1 enhances pain reflexes. Mediation through increased prostaglandin $\mathrm{E}_{2}$ levels. Agents Actions 1988; 25: 246-51.

[118] Cunha JM, Cunha FQ, Poole S, Ferreira SH. Cytokine-mediated inflammatory hyperalgesia limited by interleukin-1 receptor antagonist. Br J Pharmacol 1998; 130: 1418-24.

[119] Fu LW, Longhurst JC. Interleukin-1beta sensitizes abdominal visceral afferents of cats to ischaemia and histamine. J Physiol 1999; 521: 249-60.

[120] Fukuoka H, Kawatani M, Hisamitsu T, Takeshige C. Cutaneous hyperalgesia induced by peripheral injection of interleukin-1beta in the rat. Brain Res 1994; 657: 133-40.

[121] Inoue $\mathrm{A}$, Ikoma $\mathrm{K}$, Morioka $\mathrm{N}$, et al. Interleukin-1 $\beta$ induces substance $\mathrm{P}$ releaes from primary afferent neurons through the cyclooxygenase system. J Neurochem 1999; 73: 2206-13.

[122] Perkins MN, Kelly D. Interleukin-1 beta induceddesArg9bradykinin-mediated thermal hyperalgesia in the rat. Neuropharmacology 1994; 33: 657-60.

[123] Obreja O, Rathee PK, Lips S, Distler C, Kress M. IL-1ß potentiates heat-activated currents in rat sensory neurons: involvement of IL1RI, tyrosine kinase and protein kinase C. FASEB J 2002; 16: 1497-503.

[124] Binshtok AM, Wang H, Zimmermann K, et al. Nociceptors are interleukin-1beta sensors. J Neurosci 2008; 28: 14062-73.

[125] Amaya F, Wang H, Costigan M, et al. The voltage-gated sodium channel $\mathrm{Na}[\mathrm{v}] 1.9$ is an effector of peripheralinflammatory pain hypersensitivity. J Neurosci 2006; 26: 12852-60.

[126] Igwe OJ. c-Src kinase activation regulates preprotachykinin gene expression and substance $\mathrm{P}$ secretion in rat sensory ganglia. Eur $\mathrm{J}$ Neurosci 2003; 18: 1719-30.

[127] Skoff AM, Zhao C, Adler JE. Interleukin-1alpha regulates substance $\mathrm{P}$ expression and release in adult sensory neurons. Exp Neurol 2009; 217: 395-400.

[128] Schäfer KH, Mestres P, März P, Rose-John S. The IL-6/sIL-6R fusion protein hyper-IL-6 promotes neurite outgrowth and neuron survival in cultured enteric neurons. J Interferon Cytokine Res 1999; 19: 527-32.

[129] März P, Otten U, Rose-John S. Neural activities of IL-6-type cytokines often depend on soluble cytokine receptors. Eur J Neurosci 1999; 11: 2995-3004.

[130] März P, Cheng JG, Rose-John S. Sympathetic neurons can produce and respond to interleukin 6. Proc Natl Acad Sci USA 1998; 95: 3251-6.

[131] Qiu J, Cafferty WBJ, McMahon SB, Thompson SWN. Conditioning injury-induced spinal axon regeneration requires signal transducer and activator of transcription 3 activation. J Neurosci 2005; 25: 1645-53.

[132] Cafferty WBJ, Gardiner NJ, Das P, Qiu J, McMahon SB, Thompson SWN. Conditioning injury-induced spinal axon regeneration fails in interleukin-6 knock-out mice. $\mathrm{J}$ Neurosci 2004; 24: 4432-43.

[133] Gardiner NJ, Cafferty WB, Slack SE, Thompson SW. Expression of gp130 and leukaemia inhibitory factor receptor subunits in adult rat sensory neurones: regulation by nerve injury. J Neurochem 2002; 83: 100-9

[134] Obreja O, Biasio W, Andratsch M, et al. Fast modulation of heatactivated ionic current by proinflammatory interleukin 6 in rat sensory neurons. Brain 2005; 128: 1634-41.

[135] Jüttler E, Tarabin V, Schwaninger M. Interleukin-6 [IL-6]: a possible neuromodulator induced by neuronal activity. Neuroscientist 2002; 8: 268-75.

[136] Vollmer-Conna U, Fazou C, Cameron B, et al. Production of proinflammatory cytokines correlates with the sympotoms of acute sickness behaviour in humans. Psychol Med 2004; 34: 1289-97.
[137] Wang XS, Williams LA, Cleeland CS, et al. Serum interleukin-6 predicts the development of multiple symptoms at nadir of allogeneic hemaotpoietic stem cell transplantation. Cancer 2008; 113: 2102-9.

[138] Murphy PG, Ramer MS, Borthwick L, Gauldie J, Richardson PM, Bisby MA. Endogenous interleukin-6 contributes to hypersensitivity to cutaneous stimuli and changes in neuropeptides asociated with chronic nerve constriction in mice. Eur J Neurosci 1999; 11: 2243-53

[139] Xu XJ, Hao JX, Andell-Jonsson S, Poli V, Bartfai T, WiesenfeldHallin Z. Nociceptive responses in interleukin-6-deficient mice to peripheral inflammation and peripheral nerve section. Cytokine 1997; 9: 1028-33.

[140] Zhong J, Dietzel DI, Wahle P, Kopf M, Heumann R. Sensory impairments and delayed regeneration of sensory axons in interleukin-6-deficient mice. J Neurosci 1999; 19: 4305-13.

[141] Ferreira SH, Lorenzetti BB, Poole S. Bradykinin initiates cytokinemediated inflammatory hyperalgesia. Br J Pharmacol 1993; 110: 1227-31.

[142] DeLeo JA, Colburn RW, Nichols M, Malhotra A. Interleukin-6mediated hyperalgesia/allodynia and incrased spinal IL-6 expression in a rat mononeuropathy model. J Interferon Cytokine Res 1996; 16: 695-700.

[143] Okamoto K, Martin DP, Schmelzer JD, Mitsui Y, Low PA. Proand anti-inflammatory cytokine expression in rat sciatic nerve chronic constriction injury model of neuropathic pain. Exp Neurol 2001; 169: 386-91.

[144] Takeuchi E, Ito M, Mori M, et al. Lung cancer producing interleukin-6. Intern Med 1996; 35: 212-4

[145] Yamaguchi T, Yamamoto Y, Yokota S, Nakagawa M, Ito M, Ogura T. Involvement of interleukin- 6 in the elevation of plasma fibrinogen levels in lung cancer patients. Jpn J Clin Oncol 1998; 28: 740-4.

[146] Andratsch M, Mair N, Constantin CE, et al. A key role for gp130 expressed on peripheral sensory nerves in pathological pain. J Neurosci 2009; 29(43): 13473-83.

[147] Brenn D, Richter F, Schaible HG. Sensitization of unmyelinated sensory fibers of the joint nerve to mechanical stimuli by interleukin-6 in teh rat: an inflammatory mechanism of joint pain Arthritis Rheum 2007; 56: 351-9.

[148] Pusztai L, Mendoza TR, Reuben JM, et al. Changes in plasma levels of inflammatory cytokines in response to paclitaxel chemotherapy. Cytokine 2004; 25: 94-102.

[149] Arruda JL, Colburn RW, Rickman AJ, Rutkowski MD, De Leo JA. Increase of interleukin-6 mRNA in teh spinal cord following peripheral nerve injury in the rat: potential role of IL-6 in neuropathic pain. Brain Res Mol Brain Res 1998; 62: 228-35.

[150] Callizot M, Andriambeloson E, Glass J, et al. Interleukin-6 protects agains paclitaxel, cisplatin and vincristine-induced neuropathies without impairing chemotherapeutic activity. Cancer Chemother Pharmacol 2008; 62: 995-1007.

[151] Oka T, Oka K, Hosoi M, Hori T. Intracerebroventricular injection of interleukin-6 induces thermal hyperalgesia in rats. Brain Res 1995; 692: 123-8.

[152] Poole S, Cunha FQ, Selkirk S, Lorenzetti BB, Ferreira SH. Cytokine-mediated inflammatory hyperalgesia limited by interleukin-10. Br J Pharmacol 1995; 115: 684-8.

[153] Rose-John S, Heinrich P. Soluble receptors for cytokines and growht factors: generation and biological function. Biochem $\mathrm{J}$ 1994; 300: 281-90

[154] Taga $\mathrm{T}$, Hibi $\mathrm{M}$, Hirata $\mathrm{Y}$, et al. Interleukin-6 triggers the association of its receptor with a possible signal transducer, gp130. Cell 1989; 58: 573-81.

[155] Fischer A, Goldschmitt J, Peschel C, et al. A bioactive designer cytokine for human haematopoietic progenitor cell expansion. Nat Biotechnol 1997; 15: 142-5.

[156] Obreja O, Schmelz M, Poole S, Kress M. Interleukin-6 in combination with its soluble IL-6 receptor sensitises rat skin nociceptors to heat, in vivo. Pain 2002; 96: 57-62.

[157] Rabe B, Chalaris A, May U, et al. Transgenic blockade of interleukin 6 transsignaling abrogates inflammation. Blood 2008; 111: $1021-8$.

[158] Melton L, Coombs A. Actemra poised to launch IL-6 inhibitors. Nat Biotechnol 2008; 26: 957-9.

[159] Smolen JS, Beaulieu A, Rubbert-Roth A, et al. Effect of interleukin-6 receptor inhibition with tocilizumab in patients with 
rheumatoid arthritis [OPTION study]: a double-blind, placebocontrolled, randomised trial. Lancet 2008; 371: 987-97.

[160] Hamilton JA. Colony-stimulating factors in inflammation and autoimmunity. Nat Rev Immunol 2008; 8: 532-44.

[161] Schweizerhof M, Stösser S, Kurejova M, et al. Hematopoietic colony-stimulating factors mediate tumor-nerve interactions and bone cancer pain. Nat Med 2009; 15: 802-7.

[162] Hercus TR, Thomas D, Gurthridge MA, et al. The granulocytemacrophage colony-stimulating factor receptor: linking its strucutre to cell signalling and its role in disease. Blood 2009; 114: 1289-98.

[163] Cunha TM, Verri WA, Schivo IR, et al. Crucial role of neutrophils in the development of mechanical inflammatory hypernociception. J Leukoc Biol 2008; 83: 824-32.

[164] Verri WA, Cunha TM, Parada CA, et al. IL-15 mediates immune inflammatory hypernociception by triggering a sequential release of IFN- $\gamma$, endothelin, and prostaglandin. Proc Natl Acad Sci USA 2006; 103: 9721-5.

[165] Verri WA, Cunha TM, Parada CA, et al. Antigen-induced inflammatory mechanical hypernociception in mice is mediated by IL-18. Brain Behav Immun 2006; 21: 535-43.

[166] Verri WA, Guerrero AT, Fukada SY, et al. IL-33 mediates antigeninduced cutaneous and articular hypernociception in mice. Proc Natl Acad Sci USA 2008; 105: 2723-8.

[167] Abbadie C. Chemokines, chemokine receptors and pain. Trends Immunol 2005; 26: 529-34.

[168] Zlotnik A, Yoshie O. Chemokines: a new classification system and their role in immunity. Immunity 2000; 12: 121-7.

[169] Murdoch C, Finn A. Chemokine receptors and their role in inflammation and infectious diseases. Blood 2000; 95: 3032-43.

[170] Horuk R. Chemokine receptor antagonists: overcoming developmental hurdles. Nat Rev Drug Discov 2009; 8: 23-33.

[171] Murphy PM, Baggiolini M, Charo IF, et al. International union of pharmacology. XXII. Nomenclature for chemokine receptors. Pharmacol Rev 2000; 52: 145-56.

[172] Murphy PM. International union of pharmacology. XXX. Update on chemokine receptor nomenclature. Pharmacol Rev 2002; 54: 227-9.

[173] Qin X, Wan Y, Wang X. CCL2 and CXCL1 trigger cacitonin generelated peptide release by exciting primary nociceptive neurons. J Neurosci Res 2005; 82: 51-62.

[174] Sun JH, Yang B, Donnelly DF, Ma C, LaMotte RH. MCP-1 enhances excitability of nociceptive neurons in chronically compressed dorsal root ganglia. J Neurophysiol 2006; 96: 2189-99.

[175] Bogen O, Dina OA, Gear RW, Levine JD. Dependence of monocyte chemoattractant protein 1 induced hyperalgesia on the isolectin B4-binding protein versican. Neuroscience 2009; 159: 780-6.

[176] Jung H, Toth PT, White FA, Miller RJ. Monocyte chemoattractant protein-1 functions as a neuromodulator in dorsal root ganglia neurons. J Neurochem 2008; 104: 254-63.

[177] Onuffer JJ, Horuk R. Chemokines, chemokine receptors and smallmolecule antagonists: recent developments. Trends Pharmacol Sci 2002; 23: 459-67.

[178] Slettenaar VI, Wilson JL. The chemokine network: a target in cancer biology? Adv Drug Deliv Rev 2006; 58: 962-74.

[179] Hefti FF, Rosenthal A, Walicke PA, et al. Novel class of pain drugs based on antagonism of NGF. Trends Pharmacol Sci 2006; 27: 8591.

[180] Dolle L, El Yazidi-Belkoura I, Andraenssens E, Nurcombe V, Hondermarck H. Nerve growth factor overexpression and autocrine loop in breast cancer cells. Oncogene 2003; 22: 5592-601.

[181] Vega JA, Garcia-Suarez O, Hannestad J, Perez-Perez M, Germana A. Neurotrophins and the immune system. J Anat 2003; 203: 1-19.

[182] Dang C, Zhang Y, Ma Q, Shimahara Y. Expression of nerve growth factor receptors is correlated with progression and prognosis of human pancreatic cancer. J Gatroenterol Hepatol 2006; 232: 90-8

[183] Takei Y, Laskey R. Interpreting crosstalk between TNF-alpha and NGF: potential impflications for disease. Trends Mol Med 2008; 14: 381-8.

[184] Jaggar SI, Scott HC, Rice AS. Inflammation of the rat urinary bladder is associatedwith a refered thermal hyperalgesia which is nerve growth factor dependent. Br J Anaesth 1999; 83: 442-8.
[185] Koltzenburg M, Bennett DL, Shelton DL, McMahon SB. Neutralization of endogenous NGF prevents the sensitization of nociceptors supplying inflamed skin. Eur J Neurosci 1999; 11: 1698-704.

[186] Sevcik MA, Ghilardi JR, Peters CA, et al. Anti-NGF therapy profoundly reduces bone cancer pain and the accompanying increase in markers of peripheral and central sensitization. Pain 2005; 115: 128-41.

[187] Halvorson KG, Kubota K, Sevcik MA, et al. A blocking antibody to nerve growth factor attenuates skeletal pain induced by prostate tumor cells growing in bone. Cancer Res 2005; 65: 9426-35.

[188] Nicol GD, Vasko MR. Unraveling the story of NGF-mediated sensitization of nociceptive sensory neurons: on or off the trks? Mol Interv 2007; 7: 26-41.

[189] Watson JJ, Allen SJ, Dawbarn D. Targeting nerve growth factor in pain: what is the therapeutic potential. BioDrugs 2008; 22: 349-59.

[190] Negri L, Lattanzi R, Giannini E, Melchiorri P. Modulators of pain: bv8 and prokineticins. Curr Neuropharmacol 2006; 4[207]: 215.

[191] Kraft A, Weindel K, Ochs A, et al. Vascular endothelial growth factor in the sera and effusions of patients with malignant and nonmalignant disease. Cancer 1999; 85: 178-87.

[192] Jiang X, Abiatari I, Kong B, et al. Pancreatic islet and stellate cells are the main sources of endocrine gland-derived vascular endothelial growth factor/prokineticin-1 in pancreatic cancer. Pancreatology 2009; 9: 165-72.

[193] Vellani V, Colucci M, Lattanzi R, et al. Sensitization of transient receptor potential vanilloid 1 by the prokineticin receptor agonist Bv8. J Neurosci 2006; 26: 5109-16.

[194] Hu WP, Zhang C, Li JD, et al. Impaired pain sensation in mice lacking prokineticin 2. Mol Pain 2006; 2: 35-43.

[195] Negri L, Lattanzi R, Giannini E, et al. Impaired nociception and infalmmatory pain sensation in mice lacking the prokineticin receptor PKR1: focus on interaction between PKR1 and teh capsaicin receptor TRPV1 in pain behavior. J Neurosci 2006; 26: 6716-27.

[196] Beenken A, Mohammadi M. The FGF family: biology, pathophysiology and therapy. Nat Rev Drug Discov 2009; 8: 23553.

[197] Furushu M, Dupree JL, Bryant M, Bansal R. Disrupion of fibroblast growth factor receptor signaling in nonmyelinating Schwann cells causes sensory axonal neuropathy and impairment of thermal pain sensitivity. J Neurosci 2009; 29: 1608-14.

[198] Gill SE, Parks WC. Metalloproteinases and their inhibitors: regulators of wound healing. Int J Biochem Cell Biol 2008; 40: 1334-47.

[199] Bonfil RD, Chinni S, Fridman R, Kim HR, Cher ML. Proteases, growth factors, chemokines, and the microenvironment inprostate cancer bone metastasis. Urol Oncol 2007; 25: 407-11.

[200] Elliott S, Cawston T. The clinical potential of matrix metalloproteinase inhibitors in the rheumatic disorders. Drugs Aging 2001; 18: 87-99.

[201] Milner JM, Cawston T. Matrix metalloproteinaes kchockout studies and the potential use of matrix metallosproteinase inhibitors in the rheumatic diseases. Curr Drug Targets Inflamm Allergy 2005; 4: 363-75.

[202] Burrage PS, Brinckerhoff CE. Molecular targets in osteoarthritis: metallproteinases and their inhibitors. Curr Drug Targets 2007; 8: 293-303.

[203] Chattopadhyay S, Myers RR, Janes J, Shubayev VI. Cytokine regulation of MMP-9 in peripheral glia: implications for pahtological processes and pain in injured nerve. Brain Behav Immun 2007; 21: 561-8.

[204] Shubayev VI, Angert M, Dolkas J, Campana WM, Palenscar K, Myers RR. TNF-alpha-induced MMP-9 promotes macrophage recruitment into injured peripheral nerve. Mol Cell Neurosci 2006; 31: 407-15.

[205] Kobayashi H, Chattopadhyay S, Kato K, et al. MMPs initiate Schwann cell-mediated MBP degradation and mechanical nociception after nerve damage. Mol Cell Neurosci 2008; 39: 61927.

[206] Nishida K, Kuchiiwa S, Oiso S, et al. Up-regulation of matrix metalloproteinase-3 in the dorsal root ganglion of rats with paclitaxel-induced neuropathy. Cancer Sci 2008; 99: 1618-25. 
[207] Kawasaki Y, Zhang L, Cheng JK, Ji RR. Cytokine mechanisms of central sensitization: distinct and overlapping role of interleukin1 beta, interleukin-6, and tumor necrosis factor-alpha in regulating synaptic and neuronal activity in the superficial spinal cord. $\mathbf{J}$ Neurosci 2008; 28: 5189-94.

[208] Ji RR, Xu ZZ, Wang X, Lo EH. Matrix metalloprotease regulation of neuropathic pain. Trends Pharmacol Sci 2009; 30: 336-40.
[209] Üceyler N, Rogausch JP, Toyka KV, Sommer C. Differential expression of cytokines in painful and painless neuropathies. Neurology 2007; 69: 42-9.

[210] Üceyler N, Sommer C. Status of immune mediators in painful neuropathies. Curr Pain Headache Rep 2009; 12: 159-64.

(C) Michaela Kress; Licensee Bentham Open.

This is an open access article licensed under the terms of the Creative Commons Attribution Non-Commercial License (http://creativecommons.org/licenses/by-nc/3.0/) which permits unrestricted, non-commercial use, distribution and reproduction in any medium, provided the work is properly cited. 


\section{REFERENCES}

[1] FDA (2006) Drug interaction studies - study design, data analysis, and implications for dosing and labeling. http://WWW.FDA.gov/cder/guidence/6695dft.htm.

[2] Hoing PK, Wortham DC, Zamani K, Conner DP, Mullin JC, Cantilena LR. Terfenadine-ketoconazole: pharmacokinetics and electrocardiographic consequences, JAMA 1993; 269: 1513-9.

[3] Markham MA, Wagstaff AJ. Fexofenadine, Drugs 1998; 55: 26974.

[4] Abdel-Aziz MT, Wiliams KI. Metabolism of radioactive 17aethynylestradiol by women. Steroids 1970; 15: 695-710.

[5] Li AP, Hartman NR, Lu C, Collins JM, Strong JM.Effects of cytochrome P450 inducers on 17a-ethynylestradiol (EE2) conjugation in primary human hepatocytes. Br J Clin Pharmacol 1999; 48: 733-42.

[6] Back DJ, Breckenridge AM, Orawford FE, et al. The effect of rifampicin on the Pharmacokinetics of ethynyestradiol in women. Contraception 1980; 21: 255-81.

[7] Bachmann KA. Inhibition constants, inhibitor concentrations and the prediction of inhibitory drug drug interaction: Pitfalls, progress and promise. Curr Drug Metab 2006; 7: 1-14.

[8] Xia CQ, Milton MN, Gan LS. Evaluation of drug-transporter interactions using in vitro and in vivo models. Curr Drug Metab 2007; 8: 341-63

[9] Zhang L, Reynolds KS, Zhao P, Huang S-M. Drug interactions evaluation: An integrated part of risk assessment of therapeutics. Toxicol Appl Pharmacol 2010; 243(2): 134-45. Epub 2010 Jan 4.

[10] Clarke SE. In vitro assessment of human cytochrome P450. Xenobiotica 1998; 28: 1167-202.

[11] Venkatakrishnan K, von Moltke LL, Greenblatt DJ. Application of the relative activity factor approach in scaling from heterologously expressed cytochromes $\mathrm{p} 450$ to human liver microsomes: studies on amitriptyline as a model substrate. J Pharmacol Exp Ther 2001; 297(1): 326-37.

[12] Uttamsingh V, Lu C, Miwa G, Gan LS. Relative contributions of the five major human Cytochromes P450, 1A2, 2C9, 2C19, 2D6, and $3 \mathrm{~A} 4$, to the hepatic metabolism of the proteasome inhibitor Bortezomib. Drug Metab Dispos 2005; 33: 1723-8.

[13] Crespi CL, Penman BW. Use of cDNA-expressed human cytochrome P450 enzymes to study potential drug-drug interactions. Adv Pharmacol 1997; 43: 171-88.

[14] Crespi CL. Xenobiotic-metabolizing human cells as tools for pharmacological and toxicological research. Adv Drug Res 1995; 26: $179-235$.

[15] Venkatakrishnan K, von Moltke LL, Court MH, Harmatz JS, Crespi CL, Greenblatt DJ. Comparison between cytochrome P450 (CYP) content and relative activity approaches to scaling from cDNA-expressed CYPs to human liver microsomes: ratios of accessory proteins as sources of discrepancies between the approaches. Drug Metab Dispos 2000; 8(12): 1493-504.

[16] Emoto C, Murase S, Iwasaki K. Approach to the prediction of the contribution of major cytochrome P450 enzymes to drug metabolism in the early drug-discovery stage. Xenobiotica 2006; 36(8): 671-83.

[17] Protor NJ, Tucker GT, Rostami-Hodjegan A. Predicting drug clearance from recombinantly expressed CYPs: intersystem extrapolation factors. Xenobiotica 2004; $\mathrm{http}: / /$ www.informaworld.com/smpp/title $\sim \mathrm{db}=\mathrm{all} \sim$ content=t713698 011 tab=issueslist $\sim$ branches $=34-\mathrm{v} 3434(2):$ 151-78.

[18] Youdim KA, Zayed A, Dickins M, et al. Application of CYP3A4 in vitro data to predict clinical drug-drug interactions; predictions of compounds as objects of interaction. Br J Clin Pharmacol 2008; 65(5): 680-92.

[19] Emoto C, Iwasaki K. Approach to predict the contribution of cytochrome P450 enzymes to drug metabolism in the early drugdiscovery stage: The effect of the expression of cytochrome b5 with recombinant P450 enzymes. Xenobiotica 2007; 37(9): 986-99.

[20] Lu C, Miwa GT, Prakash SR, Gan LS, Balani SK. A novel model for the prediction of drug-drug interactions in humans based on in vitro CYP phenotyping. Drug Metab Dispos 2007; 35: 79-85.

[21] Lu C, Berg C, Prakash SR, Lee FW, Balani SK. Prediction of pharmacokinetic drug-drug interactions using human hepatocyte suspension in plasma - part II. In vitro - in vivo correlation with fluconazole. Drug Metab Dispos 2008a; 36: 1255-60.

[22] Lu C, Hatsis P, Berg C, Lee FW, Balani SK. Prediction of pharmacokinetic drug-drug interactions using human hepatocyte suspension in plasma - part III. In vitro - in vivo correlation with ketoconazole. Drug Metab Dispos 2008b; 36: 1261-6.

[23] Rodrigues AD. Prioritization of Clinical Drug Interaction Studies Using In vitro Cytochrome P450 Data: Proposed Refinement and Expansion of the "Rank Order" Approach. Drug Metabolism Letters 2007; 1: 31-5.

[24] Fowler S, Zhang H. In vitro Evaluation of Reversible and Irreversible Cytochrome P450 Inhibition: Current Status on Methodologies and their Utility for Predicting Drug-Drug Interactions. AAPS J 2008; 10(2): 410-24.

[25] Lin HL, Kent UM, Hollenberg PF. Mechanism-based inactivation of cytochrome P450 3A4by 17a-ethynylestradiol: evidence fro heme destraction and covalent binding to protein. J Pharmacol Exp Ther 2002; 301: 160-7.

[26] Grimm SW, Einolf HJ, Hall SD, et al. The conduct of in vitro studies to address time-dependent inhibition of drug metabolizing enzymes: a perspective of the pharmaceutical research and manufactures of America. Drug Metab Dispos 2009; 37: 1355-70.

[27] Zhao P, Kunze KL, Lee CA. Evaluation of time-dependent inactivation of CYP3A in cryopreserved human hepatocytes. Drug Metab Dispos 2005; 33: 853-61.

[28] McGinnity DF, Berry AJ, Kenny J, Grime K, Riley RJ. Evaluation of time-dependent cytochrome P450 inhibition using cultured human hepatocytes. Drug Metab Dispos 2006; 34: 1291-300. Maier A, Zimmermann C, Beglinger C, Drewe J, Gutmann H Effects of budesonide on P-glycoprotein expression in intestinal cell lines. $\mathrm{Br}$ J Pharmacol 2007; 150: 361-8.

[29] Xu L, Chen Y, Pan Y, Skiles GL, Shou M. Predictions human drug-drug interactions from time-dependent inactivation of CYP3A in primary hepatocytes using a population-based simulator. Drug Metab Dispos 2009; 37: 2330-9.

[30] Zhao P, Lee CA, Kunze KL. Sequential metabolism is responsible for diltiazem-induced time-dependent loss of CYP3A. Drug Metab Dispos 2007; 35: 704-12.

[31] Ohyama K, Nakajima, Suzuki M, Shimada N, Yamazaki H, Yokoi $\mathrm{T}$. Inhibitiory effect of amiodarone and its N-deethylated metabolite on human cytochrome P450 activities: prediction of in vivo drug. Br J Clin Pharmacol 2000; 49: 244-53.

[32] Li P, Lu C, Daniels JS, Miwa G, Gan LS. CYP3A4 mediated timeand concentration-dependent CYP2D6 inhibition by a melanocortin receptor antagonist, Drug Metab Rev 2004; 36(Supplement1): 572.

[33] Obach RS, Walsky RL, Venkatakrishnan K. Mechanism-based inactivation of human cytochrome p450 enzymes and the prediction of drug-drug interactions. Drug Metab Dispos 2007; 35: 246-55.

[34] Berry LM, Zhao Z. An examination of IC50 and IC50-shift experiments in assessing time-dependent inhibition of CYP3A4, CYP2D6, and CYP2C9 in human liver microsomes. Drug Metab Lett 2008; 2 : 51-9.

[35] Burt HJ, Galtin A, Houston JB. $\mathrm{IC}_{50}$-based approches as an alternative method for assessment of time-dependent inhibition of CYP3A4. Xenobiotica 2010; 40: 331-43.

[36] Li P, Lu C, Daniels JS, Labutti J, Miwa GT, Gan LS. A modified inhibition assay to identify CYP3A4 mechanism-based inhibitors. Drug Metab Rev 2005; 37 (Supplement 2): 254.

[37] Segel HS. Enzyme kinetics, John Wiley \& Son, Inc, New York, 1974.

[38] Galetin A, Houston JB. Inhibition of Drug Metabolizing Enzymes in Gastrointestinal Tract and its Influence on the Drug-Drug Interaction Prediction, in Enzyme Inhibition in Drug Discovery and Development: The Good and The Bad (Lu C and Li AP eds), John Wiley \& Sons, New York, 2010.

[39] Yang J, Jamei M, Yeo KR, Tucker GT, Rostami-Hodjegan A. Prediction of intestinal first-pass drug metabolism. Curr Drug Metab 2007; 8: 676-84.

[40] Thummel KE, Wilkinson GR. In vitro and in vivo drug interactions involving human CYP3A4. Annu Rev Pharmacol Toxicol 1998; 38: $389-430$ 
[41] Galetin A, Ito K, Hallifax D, Houston JB. CYP3A4 substrate selection and substitution in the prediction of potential drug-drug interactions. J Pharmacol Exp Ther 2005; 314: 180-90.

[42] Stresser DM, Broudy MI, Ho T, et al. Highly selective inhibition of human CYP3A in vitro by azamulin and evidence that inhibition is irreversible. Drug Metab Dispos 2004; 32: 105-12.

[43] Ito K, Brown H, Houston JB. Database analyses for prediction of in vivo drug-drug interactions from in vitro data. Br J Clin Pharmacol 2004; 57: 473-86.

[44] Blanchard N, Richert L, Coassolo P, Lave T. Qualitative and Quantitative assessment of drug-drug interaction potential in man, based on Ki, IC50 and inhibitor concentration. Curr Drug Metab 2004; 5 : 147-56.

[45] Cook CS, Berry LM, Burton E. Prediction of in vivo drug interaction with eplerenone in man from in vitro metabolic inhibition data. Xenobiotica 2004; 34: 215-28.

[46] Obach RS, Walsky RL, Venkatakrishnan K, Gaman EA, Houston JB, Tremaine LM. The utility of in vitro cytochrome P450 inhibitioon data in the prediction of drug- drug interactions. J Pharmacol Exp Ther 2006; 316: 336-48.

[47] Shitara Y, Li AP, Kato Y, et al. Function of uptake transporters for taurocholate and estradiol 17b-D-glucuronide in cryopreserved human hepatocytes. Drug Metab Pharmacokinet 2003; 18: 33-41

[48] Liu XR, LeCluyse EL, Brouwer KR, et al. Biliary excretion in primary rat hepatocytes culture in a collagen-sandwich configuration. Am J Physiol 1999; 277: G12-G21.

[49] Salphati L, Benet LZ. Effect of ketoconazole on digoxin absorption and disposition in rat. Pharmocology 1998; 56: 308-13.

[50] Achira M, Ito K, Suzuki H, Sugiyama Y. Comparative studies to determine the selective inhibitors fro P-Glycoprotein and cytochrome P4503A4. AAPS Pharmsci 1999; 1: 1-6.

[51] Kodawara $\mathrm{T}$, Yono I, Masuda $\mathrm{S}$, et al. Interaction of azole antifungal agent with human p-glycoprotein expressed in a kidney epithelial cell line LLC-PK1. Yakubutsu Dotai 2001; 16: 5-11.

[52] Soars MG, Gelboin HV, Krausz KW, Riley RJ. A comparison of relative abundance, activity factor and inhibitory monoclonal antibody approaches in the characterization of human CYP enzymology. Br J Clin Pharmacol 2003; 55: 175-181.

[53] Lu C, Balani SK, Qian MG, Prakash SR, Ducray PS,von Moltke LL. Quantitative prediction and clinical observation of a CYP3A inhibitor-based drug - drug interactions with MLN3897, a potent CCR1 antagonist. J Pharmacol Exp Ther 2010; 332: 562-8.

[54] Yang J, Liao M, Shou M, et al. Cytochrome p450 turnover: regulation of synthesis and degradation, methods for determining rates, and implications for the prediction of drug interactions. Curr Drug Metab 2008; 9(5): 384-94.

[55] Fontana E, Dansette PM, Poli SM. Cytochrome P450 enzyme mechanism based inhibitions: Common sub-structures and reactivity. Drug Metab Rev 2005; 6: 413-54.

[56] Zhou S, Chan E, Duan W, Huang, Chen YZ. Drug bioactivation, covalent binding to target proteins and toxicity relevance. Drug Metab Rev 2005; 1: 41-213.

[57] Hewitt NJ, Lechón MJ, Houston JB, et al. Primary hepatocytes: current understanding of the regulation of metabolic enzymes and transporter proteins, and pharmaceutical practice for the use of hepatocytes in metabolism, enzyme induction, transporter, clearance, and hepatotoxicity studies. Drug Metab Rev 2007; 39: 159-234

[58] Chu V, Einolf HJ, Evers R, et al. In vitro and in vivo induction of cytochrome p450: a survey of the current practices and recommendations: a pharmaceutical research and manufacturers of america perspective. Drug Metab Dispos 2009; 37(7): 1339-54.

[59] Mills JB, Rose KA, Sadagopan N, Sahi J, de Morais SM. Induction of drug metabolism enzymes and MDR1 using a novel human hepatocyte cell line. J Pharmacol Exp Ther 2004; 309: 303-9.

[60] Kenny JR, Chen L, McGinnity DF, et al. Efficient assessment of the utility of immortalized Fa2N-4 cells for cytochrome P450 (CYP) induction studies using multiplex quantitative reverse transcriptase-polymerase chain reaction (qRT-PCR) and substrate cassette methodologies. Xenobiotica 2008; 38: 1500-17.

[61] Ripp SL, Mills JB, Fahmi OA, et al. Use of immortalized human hepatocytes to predict the magnitude of clinical drug-drug interactions caused by CYP3A4 induction. Drug Metab Dispos 2006; 34: 1742-8.

[62] Hariparsad N, Carr BA, Evers R, Chu X. Comparison of immortalized Fa2N-4 cells and human hepatocytes as in vitro models for cytochrome P450 induction. Drug Metab Dispos 2008; 36: 1046-55.

[63] McGinnity DF, Zhang G, Kenny JR, et al. Evaluation of Multiple in vitro Systems for Assessment of CYP3A4 Induction in Drug Discovery: Human Hepatocytes, Pregnane X Receptor Reporter Gene, and Fa2N-4 and HepaRG Cells. Drug Metab Dispos 2009; 37: 1259-68;

[64] Guillouzo A, Corlu A, Aninat C, Glaise D, Morel F, GuguenGuillouzo C. The human hepatoma HepaRG cells: a highly differentiated model for studies of liver metabolism and toxicity of xenobiotics. Chem Biol Interact 2007; 168: 66-73.

[65] Lankas GR, Cartwright ME, Umbenhauer D. P-glycoprotein deficiency in a subpopulation of CF-1 mice enhances avermectininduced neurotoxicity. Toxicol Appl Pharmacol 1997; 143: 357-65.

[66] Giacomini KM, Huang_SM, Tweediehttp://www.nature.com/nrd/journal/v9/n3/full/nrd3028.htm 1 - a3\#a3 DJ, et al. For The International Transporter Consortium Membrane transporters in drug development. Nat Rev Drug Discov 2010; 9(3): 215-36.

[67] Sarkadi B. PEM, Boucher RC, German UA, Scarborough GA. Expression of the human multidrug resistance cDNA insect cells generates a high activity drug-stimulated membrane ATPase. J Biol Chem 1992; 267: 4854-8.

[68] Senior AE a-SMK, Urbatsch IL. ATP hydrolysis by multidrug resistance protein from Chinese hamster ovary cells. J Bioenerg Biomembr 1995; 27: 31-6.

[69] Chang X-B, Hou Y-X, Riordan JR. Stimulation of ATPase Activity of Purified Multidrug Resistance-associated Protein by Nucleoside Diphosphates J Biol Chem 1998; 273: 23844-8.

[70] Ozvegy C, Litman T, Szakacs G, Nagy Z, Bates S, Varadi A, Sarkadi B. Functional Characterization of the Human Multidrug Transporter, ABCG2, Expressed in Insect Cells. Biochemical and Biophysical Research Communications 2001; 285: 111-7.

[71] Ozvegy C, Varadi A, Sarkadi B. Characterization of Drug Transport, ATP Hydrolysis, and Nucleotide Trapping by the Human ABCG2 Multidrug Transporter. Modulation of substrate specificity by a point mutation. J Biol Chem 2002; 277: 47980-90.

[72] Druekes P. SR, Palm D. Photometric microtiter assay of inorganic phosphate in the presence of acid-labile organic phosphates. Analytical Biochem 1995; 230: 173-7.

[73] Promega http://www.promega.com/tbs/tb341/tb341.pdf.

[74] Ramachandra M, Ambudkar SV, Gottesman MM, Pastan I, Hrycyna CA. Functional characterization of a glycine 185-to-valine substitution in human P-glycoprotein by using a vaccinia-based transient expression system. Mol Biol Cell 1996; 7: 1485-98.

[75] Scarborough GA. Drug-stimulated ATPase activity of the human P-glycoprotein. J Bioenerg Biomembr 1995; 27: 37-41.

[76] Polli JW, Wring SA, Humphreys JE, and Serabjit-Singh CS (2001) Rational Use of in vitro P-glycoprotein Assays in Drug Discovery. J Pharmacol Exp Ther 299: 620-8.

[77] Xia CQ, Liu N, Miwa G, et al. Use of in vitro models to study interactions between the breast cancer resistant protein and its ligands. Drug Metab Rev 2004; 36: 53.

[78] Garrigues A, Nugier J, Orlowski S, Ezan E. A High-Throughput Screening Microplate Test for the Interaction of Drugs with PGlycoprotein. Analytical Biochem 2002; 305: 106-14.

[79] Litman T, Zeuthen T, Skovsgaard T, Stein WD. Competitive, noncompetitive and cooperative interactions between substrates of Pglycoprotein as measured by its ATPase activity. Biochim Biophys Acta- Molecular Basis of Disease 1997; 1361: 169-76.

[80] Xia CQ, Xiao G, Liu N, et al. Comparison of Species Differences of P-Glycoproteins in Beagle Dog, Rhesus Monkey, and Human Using ATPase Activity Assays. Mol Pharm 2006; 3: 78-86.

[81] Boulton DW, DeVane CL, Liston HL, Markowitz JS. In vitro Pglycoprotein affinity for atypical and conventional antipsychotics. Life Sciences 2002; 71: 163-9.

[82] Boyer JL, Meier PJ. Characterizing mechanisms of hepatic bile acid transport utilizing isolated membrane vesicles. Methods Enzymol 1990; 192: 517-33.

[83] Meier PJ, Boyer JL. Preparation of basolateral (sinusoidal) and canalicular plasma membrane vesicles for the study of hepatic transport processes. Methods Enzymol 1990; 192: 534-45.

[84] Tabas LB, Dantzig AH. A high-throughput assay for measurement of multidrug resistance protein-mediated transport of leukotriene C4 into membrane vesicles. Anal Biochem 2002; 310: 61-6. 
[85] Keppler D, Jedlitschky G, Leier I. Transport function and substrate specificity of multidrug resistance protein. Methods Enzymol 1998; 292: 607-16

[86] Horikawa M, Kato Y, Tyson CA, Sugiyama Y. The potential for an interaction between MRP2 (ABCC2) and various therapeutic agents: probenecid as a candidate inhibitor of the biliary excretion of irinotecan metabolites. Drug Metab Dispos 2002; 17: 23-33.

[87] Hirano M, Maeda K, Matsushima S, Nozaki Y, Kusuhara H, Sugiyama $\mathrm{Y}$. Involvement of BCRP (ABCG2) in the biliary excretion of pitavastatin. Mol Pharm 2005; 68: 800-7.

[88] Meier PJ, St. Meier-Abt A, Barrett C, Boyer JL. Mechanisms of taurocholate transport in canalicular and basolateral rat liver plasma membrane vesicles. Evidence for an electrogenic canalicular organic anion carrier. J Biol Chem 1984; 259: 10614-22.

[89] Adachi Y, Kobayashi H, Kurumi Y, Shouji M, Kitano M, Yamamoto T. ATP-dependent taurocholate transport by rat liver canalicular membrane vesicles. Hepatology (Philadelphia, PA, United States) 1991; 14: 655-9.

[90] Shapiro AB, Corder AB, Ling V. P-glycoprotein-mediated Hoechst 33342 transport out of the lipid bilayer. Euro J Biochem 1997; 250: 115-21.

[91] Shapiro AB, Fox K, Lam P, Ling V. Stimulation of P-glycoproteinmediated drug transport by prazosin and progesterone. Evidence for a third drug-binding site. Euro J Biochem 1999; 259: 841-50.

[92] Ishizuka H, Konno K, Shiina T, et al. Species differences in the transport activity for organic anions across the bile canalicular membrane. J Pharmacol and Exp Ther 1999; 290: 1324-30.

[93] Ninomiya M, Ito K, Horie T. Functional analysis of dog multidrug resistance-associated protein 2 (MRP2) in comparison with rat MRP2. Drug Metab Dispos 2005; 33: 225-32.

[94] Center MS, Zhu Q, Sun H. Mutagenesis of the putative nucleotidebinding domains of the multidrug resistance associated protein (MRP). Analysis of the effect of these mutations on MRP mediated drug resistance and transport. Cytotechnology 1998; 27: 61-9.

[95] Volk EL, Schneider E. Wild-Type Breast Cancer Resistance Protein (BCRP/ABCG2) is a Methotrexate Polyglutamate Transporter. Cancer Res 2003; 63: 5538-43.

[96] Sarkadi B, Homolya L, Hollo Z. Assay and reagent kit for evaluation of multi-drug resistance in cells, in: U.S., pp 17 pp., Cont.-in-part of U.S. 15,872,014. (Solvo Biotechnology, Hung.). Us. 2001.

[97] Xia CQ, Yang JJ, Gan L-S. Breast cancer resistance protein in pharmacokinetics and drug-drug interactions. Expert Opinion on Drug Metabolism \& Toxicology 2005b; 1: 595-611.

[98] Wang E-J, Casciano CN, Clement RP, Johnson WW. In vitro flow cytometry method to quantitatively assess inhibitors of Pglycoprotein. Drug Metab Dispos 2000; 28: 522-8.

[99] Sigel E. Use of Xenopus oocytes for the functional expression of plasma membrane proteins. J Membrane Biology 1990; 117: 20121.

[100] Simonson SG, Raza A, Martin PD, et al. Rosuvastatin pharmacokinetics in heart transplant recipients administered an antirejection regimen including cyclosporine. Clin Pharmacol Ther 2004; 76: 167-77.

[101] Yamashiro W, Maeda K, Hirouchi M, Adachi Y, Hu Z, Sugiyama $\mathrm{Y}$. Involvement of transporters in the hepatic uptake and biliary excretion of valsartan, a selective antagonist of the angiotensin II AT1-receptor, in humans. Drug Metab Dispos 2006; 34: 1247-54

[102] Makhey VD, Guo A, Norris DA, Hu P, Yan J, Sinko PJ. Characterization of the regional intestinal kinetics of drug efflux in rat and human intestine and in Caco-2 cells. Pharm Res 1998; 15: 1160-7.

[103] Gutmann H, Fricker G, Torok M, Michael S, Beglinger C, Drewe J. Evidence for different ABC-transporters in Caco-2 cells modulating drug uptake. Pharm Res 1999; 16: 402-7.

[104] Taipalensuu J, Tornblom H, Lindberg G, et al. Correlation of gene expression of ten drug efflux proteins of the ATP-binding cassette transporter family in normal human jejunum and in human intestinal epithelial Caco-2 cell monolayers. J Pharmacol and Exp Ther 2001; 299: 164-70.

[105] Xia CQ, Liu N, Yang D, Miwa G, Gan L-S. Expression, localization, and functional characteristics of breast cancer resistance protein in Caco-2 cells. Drug Metab Dispos 2005a; 33: 637-43.

[106] Calcagno AM, Ludwig JA, Fostel JM, Gottesman MM, Ambudkar SV. Comparison of Drug Transporter Levels in Normal Colon,
Colon Cancer, and Caco-2 Cells: Impact on Drug Disposition and Discovery. Mol Pharm 2006; 3: 87-93.

[107] Artursson P, Karlsson J. Correlation between oral drug absorption in humans and apparent drug permeability coefficients in human intestinal epithelial (Caco-2) cells. Biochemical and Biophysical Research Communications 1991; 175: 880-5.

[108] Gan L, Moseley M, Khosla B, et al. CYP3A-like cytochrome P450-mediated metabolism and polarized efflux of cyclosporin A in Caco-2 cells. Drug Metab Dispos 1996; 24: 344-9.

[109] Cummins CL, Jacobsen W, Benet LZ. Unmasking the Dynamic Interplay between Intestinal P-Glycoprotein and CYP3A4. J Pharmacol Exp Ther 2002; 300: 1036-45.

[110] Mouly SJ, Paine MF, Watkins PB. Contributions of CYP3A4, Pglycoprotein, and Serum Protein Binding to the Intestinal First-Pass Extraction of Saquinavir. J Pharmacol Exp Ther 2004; 308: 941-8.

[111] Muller J, Lips KS, Metzner L, et al. Drug specificity and intestinal membrane localization of human organic cation transporters (OCT). Biochem Pharmacol 2005; 70: 1851-60.

[112] Neuhoff S, Ungell A-L, Zamora I, Artursson P. pH-Dependent passive and active transport of acidic drugs across Caco-2 cell monolayers. Eur J Pharm Sci 2005; 25: 211-20.

[113] Hirano M, Maeda K, Shitara Y, Sugiyama Y. Contribution of OATP2 (OATP1B1) and OATP8 (OATP1B3) to the hepatic uptake of pitavastatin in humans. J Pharmacol Exp Ther 2004; 311: 13946.

[114] Hoffmaster KA, Turncliff RZ, LeCluyse EL, Kim RB, Meier PJ, Brouwer KLR. P-glycoprotein Expression, Localization, and Function in Sandwich-Cultured Primary Rat and Human Hepatocytes: Relevance to the Hepatobiliary Disposition of a Model Opioid Peptide. Pharm Res 2004; 21: 1294-302.

[115] Liu XR, Lecluyse EL, Brouwer KR, Lightfoot RM, Lee JI, Brouwer KLR. Use of $\mathrm{Ca} 2+$ modulation to evaluate biliary excretion in sandwich-cultured rat hepatocytes. J Pharmacol Exp Ther 1999; 289: 1592-9.

[116] Kemp DC, Zamek-Gliszczynski MJ, Brouwer KLR. Xenobiotics Inhibit Hepatic Uptake and Biliary Excretion of Taurocholate in Rat Hepatocytes. Toxicol Sci 2005; 83: 207-14.

[117] Shitara Y, Sugiyama Y. Pharmacokinetic and pharmacodynamic alterations of 3-hydroxy-3-methylglutaryl coenzyme A (HMG$\mathrm{CoA})$ reductase inhibitors: drug-drug interactions and interindividual differences in transporter and metabolic enzyme functions. Pharmacol Ther 2006; 112: 71-105

[118] Liao MX, Raczynski AR, Chen M, et al. Inhibition of hepatic OATP by RNAi in sandwich-cultured human hepatocytes: An in vitro model to assess transporter-mediated drug-drug interactions. Drug Metab Dispos 2010. doi:10.1124/dmd.110.032995

[119] Backman JT, Kyrklund C, Neuvonen M, Neuvonen PJ. Gemfibrozil greatly increases plasma concentrations of cerivastatin. Clin Pharmacol Ther 2002; 72: 685-91.

[120] Shitara Y, Hirano M, Sato H, Sugiyama Y. Gemfibrozil and its glucuronide inhibit the organic anion transporting polypeptide 2 (OATP2/OATP1B1:SLC21A6)-mediated hepatic uptake and CYP2C8-mediated metabolism of cerivastatin: analysis of the mechanism of the clinically relevant drug-drug interaction between cerivastatin and gemfibrozil. J Pharmacol Exp Ther 2004; 311: 228-36.

[121] Durr D, Stieger B, Kullak-Ublick GA, et al. St John's Wort induces intestinal P-glycoprotein/MDR1 and intestinal and hepatic CYP3A4. Clin Pharmarcol Ther 2000; 68: 598-604.

[122] Fromm MF, Kaufmann HM, Fritz P, et al. The effect of rifampin treatment on intestinal expression of human MRP transporters. Am J Pathol 2000; 157: 1575-80.

[123] Greiner B, Eichelbaum M, Fritz P, et al. The role of intestinal Pglycoprotein in the interaction of digoxin and rifampin. J Clin Invest 1999; 104: 147-53

[124] Gurley BJ, Swain A, Williams DK, Barone G, Battu SK. Gauging the clinical significance of P-glycoprotein-mediated herb-drug interactions: comparative effects of St. John's wort, Echinacea, clarithromycin, and rifampin on digoxin pharmacokinetics. Mol Nutr Food Res 2008; 52: 772-9.

[125] Marchetti S, Mazzanti R, Beijnen JH, Schellens JH. Concise review: Clinical relevance of drug drug and herb drug interactions mediated by the $\mathrm{ABC}$ transporter $\mathrm{ABCB} 1$ (MDR1, P-glycoprotein). Oncologist 2007; 12: 927-41

[126] Westphal K, Weinbrenner A, Zschiesche M, et al. Induction of Pglycoprotein by rifampin increases intestinal secretion of talinolol 
in human beings: a new type of drug/drug interaction. Clin Pharmacol Ther 2000; 68: 345-55.

[127] Zschiesche M, Lemma GL, Klebingat KJ, Franke G, Terhaag B, Hoffmann A. Stereoselective disposition of talinolol in man. J Pharm Sci 2002; 91:303-11. [126] Störmer E, von Moltke LL, Perloff MD, Greenblatt DJ (2002) Differential modulation of Pglycoprotein expression and activity by non-nucleoside HIV-1 reverse transcriptase inhibitors in cell culture. Pharm Res 19: 10381045.

[128] Hamman MA, Bruce MA, Haehner-Daniels BD, Hall SD. The effect of rifampin administration on the disposition of fexofenadine. Clin Pharmacol Ther 2001; 69: 114-21.

[129] Geick A, Eichelbaum M, Burk O. Nuclear receptor response elements mediate induction of intestinal MDR1 by rifampin. J Biol Chem 2001; 276: 14581-7.

[130] Schuetz EG, Beck WT, Schuetz JD. Modulators and substrates of P-glycoprotein and cytochrome P4503A coordinately up-regulate these proteins in human colon carcinoma cells. Mol Pharmacol 1996; 49: 311-8
[131] Thummel KE, Brimer C, Yasuda K, et al. Transcriptional control of intestinal cytochrome P-4503A by lalpha, 25-dihydroxy vitamin D3. Mol Pharmacol 2001; 60: 1399-406.

[132] Mitin T, Von Moltke LL, Court MH, Greenblatt DJ. Levothyroxine up-regulates P-gp independent of the pregnane X receptor. Drug Metab Dispos 2004; 32: 779-82

[133] Maier A, Zimmermann C, Beglinger C, Drewe J, Gutmann H Effects of budesonide on P-glycoprotein expression in intestinal cell lines. Br J Pharmacol 2007; 150: 361-8.

[134] Fardel O, Morel F, Guillouzo A. P-glycoprotein expression in human, mouse, hamster and rat hepatocytes in primary culture. Carcinogenesis 1993; 14: 781-3

[135] Synold TW, Dussault I, Forman BM. The orphan nuclear receptor SXR coordinately regulates drug metabolism and efflux. Nat Med 2001; 7: 584-90.

[136] Zhang L, Zhang YD, Strong JM, Reynolds KS, Huang SM. A regulatory viewpoint on transporter-based drug interactions. Xenobiotica 2008; 38: 709-24

(C) Michaela Kress; Licensee Bentham Open.

This is an open access article licensed under the terms of the Creative Commons Attribution Non-Commercial License (http://creativecommons.org/licenses/by-nc/3.0/) which permits unrestricted, non-commercial use, distribution and reproduction in any medium, provided the work is properly cited. 